Р. Гнатюк, І. Папіш. Солонський розріз...

УДК 551.436:551.796; DOI 10.30970/gpc.2019.1.2804

СОЛОНСЬКИЙ РОЗРІЗ І ПЕРСПЕКТИВИ

ВИВЧЕННЯ ПЛЕЙСТОЦЕНУ ПЕРЕДГІР'Я КАРПАТ

Роман Гнатюк, Ігор Папіш

Львівський національний університет імені Івана Франка, romanhnatyuk@ukr.net; orcid.org/0000-0001-6661-469;

igorpapish@gmail.com; orcid.org/0000-0001-5288-7481

Анотація. Наведено результати польових досліджень двох штучних відслонень плейстоценових відкладів, які розташовані на околиці с. Солонське поблизу м. Дрогобич. Відслонення (кар'єри) розміщені у межах тераси р. Тисмениця. Висота тераси становить близько 50 м над рівнем ріки і змінюється з віддаленням від гір. Головну увагу приділено вивченню будови верхньої (покривної) товщі тераси потужністю близько 26 м та характеристиці іiі зведеного стратиграфічного розрізу. Основу товщі творять шари безкарбонатних суглинків і глин, більшою чи меншою мірою оглеєних та озалізнених. Між ними розміщені чотири горизонти похованих грунтів інтергляціального та інтерстадіального рангу.

На підставі спостережень, здійснених у полі, з'ясовано, що відклади покривної товщі мають, здебільшого, річкове походження. Розглянуто умови їхнього нагромадження, а також умови формування та перетворення давніх грунтів; виокремлено вісім доголоценових літо- і педостратиграфічних шарів різного рангу. Обгрунтовано поділ покривної товщі тераси на три головні шари, еквівалентні стратиграфічним підрозділам льодовикового та міжльодовикового рангу.

Зіставлення солонського розрізу з іншими розрізами терас близької висоти, зокрема із відомим відслоненням поблизу с. Дубрівка (розріз Дубрівка), дає підстави вважати, що утворення місцевої тераси відбувалось під час 12-ї, 11-ї і 10-ї стадій морської ізотопної шкали. Отже, солонський розріз представляє короткий стратиграфічний інтервал середнього плейстоцену (а не три головні підрозділи плейстоцену, як засвідчують результати його попереднього дослідження) і може бути опорним для вивчення лише кількох (двохтрьох) горизонтів льодовикового/міжльодовикового рангу. Водночас це потенційно дуже важливий опорний розріз солонської (дубрівської, довгівської, варницької) тераси Придністер'я.

Вивчення солонських відслонень спонукає до перегляду популярних нині уявлень про походження й вік так званої покривної товщі річкових терас Передкарпатської височини та Подільського Придністер'я, їі стратиграфічне наповнення й значення.

Ключові слова: алювіальні відклади; тераси; грунтово-лесова послідовність; середній плейстоцен; долина Дністра; передгір'я Карпат; розріз Солонське.

\title{
SOLONSKE SECTION AND THE PERSPECTIVES OF THE STUDY OF PLEISTOCENE CARPATHIAN FORELAND
}

Roman Hnatiuk, Ivan Franko National University of Lviv; Igor Papish, Ivan Franko National University of Lviv

Abstract. The article presents the results of the field study of the two artificial outcrops of the Pleistocene deposits, which are located in the suburbs Solonske near

(C) Гнатюк Роман, Папіш Ігор, 2019. 
Р. Гнатюк, І. Папіш. Солонський розріз...

Drohobych city. Outcrops (careers) are located within the terrace of the Tysmenytsia River. The height of the terrace is about $50 \mathrm{~m}$ above the river level and changes along the distance from the mountains. The main attention in the article is paid to the study of the structure of the upper (covering) stratum of the terrace with a thickness of about 26 $\mathrm{m}$, and also to the characteristics of its consolidated stratigraphic section. The basis of this stratum consists of the layers of non-carbonate loams and clays. They are more or less enriched of iron compounds and gleyed. Between them there are four horizons of buried soils of the interglacial and interstadial rank.

Based on the observations made in the field, it was found that the sediments of the covering stratum have mainly river origin. The conditions of their accumulation, as well as the conditions for the formation and transformation of ancient soils, are considered; eight pre-Holocene lito- and pedostratigraphic layers of different rank are singled out. The division of the covering stratum of the terraces into three main layers is substantiated, which is equivalent to the stratigraphic units of the glacial and interglacial rank.

Comparison of the Solonske section with other sections of the similar height terraces, in particular with well-known outcrops near the village Dubrivka (section Dubrivka) gives grounds to assume that the formation of a local terrace occurred during the Marine Isotopic Stages 12 to 10. Consequently, the Solonske section represents a short stratigraphic interval of the Middle Pleistocene (not the three main Pleistocene units as stated in the results of its previous study). It can be the basis for studying only a few (two to three) horizons of the glacial/interglacial rank. At the same time, it is potentially a very important key section of the Solonske (Dubrivska, Dovhivska, Varnytska) terrace of the Pre-Dniester.

The studying of Solonske outcrops makes it necessary to revise the popular notions about the origin and the age of the so-called covering stratum of the river terraces of the Carpathian Foreland and Podolian Pre-Dniester, its stratigraphic filling and significance.

Key words: alluvial deposits; terraces; soil-loess sequence; Middle Pleistocene; Dniester valley; Carpathian Foreland; Solonske section.

Вступ. Відомо (напр., Адаменко та ін., 1996; Чепалыга, 1986; Gozhik, Lindner, 2007), що верхні, супіщано-суглинисті горизонти порівняно давніх (допізньоплейстоценових) річкових терас рівнинного Придністер'я місцями досягають значної (до 20-30 м і більше) товщини і містять значну кількість (до 5-6 і більше) добре розвинених похованих грунтів. Останні розглядають (Веклич, 1982; Гнатюк, 2014 та ін.) як своєрідні стратиграфічні репери, важливі не лише для стратиграфії конкретних терасових розрізів, а й для розрізнення й розпізнавання різновікових плейстоценових терас, їхньої місцевої та регіональної кореляції. Утім, існують суттєво різні уявлення про стратиграфічний ранг викопних грунтів і шарів, що їх розділяють і вкривають, про вік i стратиграфічну повноту конкретних розрізів терасових відкладів Верхнього та Середнього Придністер'я, тісно пов'язані з різними уявленнями щодо будови та генезису супіщано-суглинистих горизонтів терас.

Згідно з поглядами, які домінують (напр., Адаменко та ін., 1996; Веклич, 1982; Чепалыга, 1986; Gozhik \& Lindner, 2007; Łanczont et al., 2019; Lessy i paleolit ..., 2002), зазначені горизонти місцевих терас $\epsilon$, зазвичай, субаеральними 
еоловими та еолово-делювіальними покривами, накладеними на алювій, представлений, здебільшого, русловими відкладами; ці ж покриви, вміщуючи значну кількість викопних грунтів інтергляціального типу, творять основу опорних розрізів плейстоцену Придністер'я. На думку інших дослідників, зокрема першого автора статті (Гнатюк, 2008; Гнатюк, 2014), так звані багатоярусні покривні товщі (іх називають також грунтово-лесовими або лесовогрунтовими покривами, бо вони містять горизонти похованих грунтів) порівняно давніх річкових терас Верхнього та Середнього Придністер'я складені, зазвичай, із ярусів настеленого заплавного алювію і у верхній частині майже усіх відомих відслонень терасових відкладів (розрізи Дубрівка, Торгановичі 1, Торгановичі 2, Загвіздя та ін.) Українського Передкарпаття, які розглядають як опорні чи потенційно опорні розрізи місцевого плейстоцену (напр., Гляціал і перигляціал ..., 2011; Lessy i paleolit ..., 2002), наявні лише алювіальні яруси пилуватих (лесоподібних) відкладів, утворені, як і сформовані на них викопні грунти, за порівняно короткі проміжки часу, сумірні зі стадіалами, інтертермалами, інтерстадіалами тощо.

Для генетичної і вікової інтерпретації відкладів та грунтових утворень супіщано-суглинистих горизонтів ранньо- i середньоплейстоценових терас Українського Передкарпаття достатньо інформативним і показовим $є$ штучне відслонення терасових відкладів, зведений розріз якого детально описаний у нещодавно опублікованій праці (Богуцький, Яцишин, Дмитрук і Томенюк, 2016). У пропонованій статті наведено деякі нові відомості, важливі для всебічної описової характеристики цього цікавого й масштабного розрізу і генетичної та стратиграфічної інтерпретації його головних шарів. Додано також інформацію про будову та стратиграфію двох інших штучних відслонень-кар'єрів, розміщених поблизу головного розрізу й не згаданих у зазначеній вище праці.

Розташування розрізів та стан їхнього вивчення. Вивчені нами розрізи (C-2 і С-3 на рис. 1) приурочені до глиняних кар'єрів, розміщених у центральній частині Дрогобицької височини біля південно-східної околиці с. Солонське. Основним об'єктом досліджень була протяжна (близько 350 м) одно- й двох'ярусна північно-східна стінка більшого глинища, розташованого безпосередньо біля цегельні. Це відслонення разом із невеликими ямами та ровами, локалізованими на дні кар'єру, називатимемо розрізом (відслоненням) Солонське 2. Саме його зведений розріз описаний у недавно опублікованій праці (Богуцький та ін., 2016). Інший розріз (С-3 на рис. 1) приурочений до південнозахідного краю порівняно невеликого глинища, експлуатацію якого призупинено кілька років тому. Відповідно, розкритість товщі терасових відкладів тут значно гірша, ніж у головному кар'єрі; меншою є і його глибина. Ще один розріз (C-1 на рис. 1), просторово пов'язаний з уже рекультивованим кар'єром, свого часу опрацьований М. Векличем (фрагмент топографічної карти, поданий на рис. 1, відображає місцевість станом на 1989 р.; вихідний масштаб карти - 1:50 000). Його зображення у вигляді схематичної літолого-стратиграфічної колонки (рис. 42, г) подано, зокрема, у праці (Веклич, 1982).

Усі три розрізи розкривають будову річкової тераси, яка займає центральну частину передгірної ділянки межиріччя Тисмениці-Стрию і виступає у вигляді розлогої вершинної поверхні, розчленованої долинами невеликих постійних i тимчасових водотоків. $€$ вагомі підстави вважати, що тераса утворена діяльністю 
Р. Гнатюк, І. Папіш. Солонський розріз...

кількох річок - насамперед Тисмениці та Стрию i, меншою мірою, Дністра. За назвою опорних розрізів, розміщених у районі с. Солонське, пропонуємо називати ії солонською.

Поверхня солонської тераси на більшій частині ії поширення у межах межиріччя Тисмениці-Стрию нахилена на північний схід. У цьому ж напрямку - з віддаленням від Карпат - дещо знижуються і відносні висоти тераси, які є помітно різними стосовно Тисмениці та Стрию. Зокрема, перевищення поверхні тераси над р. Тисмениця у районі Солонського досягає 50 м, тоді як навпроти північної околиці м. Стрий, яка розміщена приблизно на тій же відстані (19-20 км) від краю гір, що і с. Солонське, їі перевищення над р. Стрий становить близько 25 м. Абсолютна висота найвищих фрагментів тераси поблизу Солонського сягає 312 315 м (рис. 1).

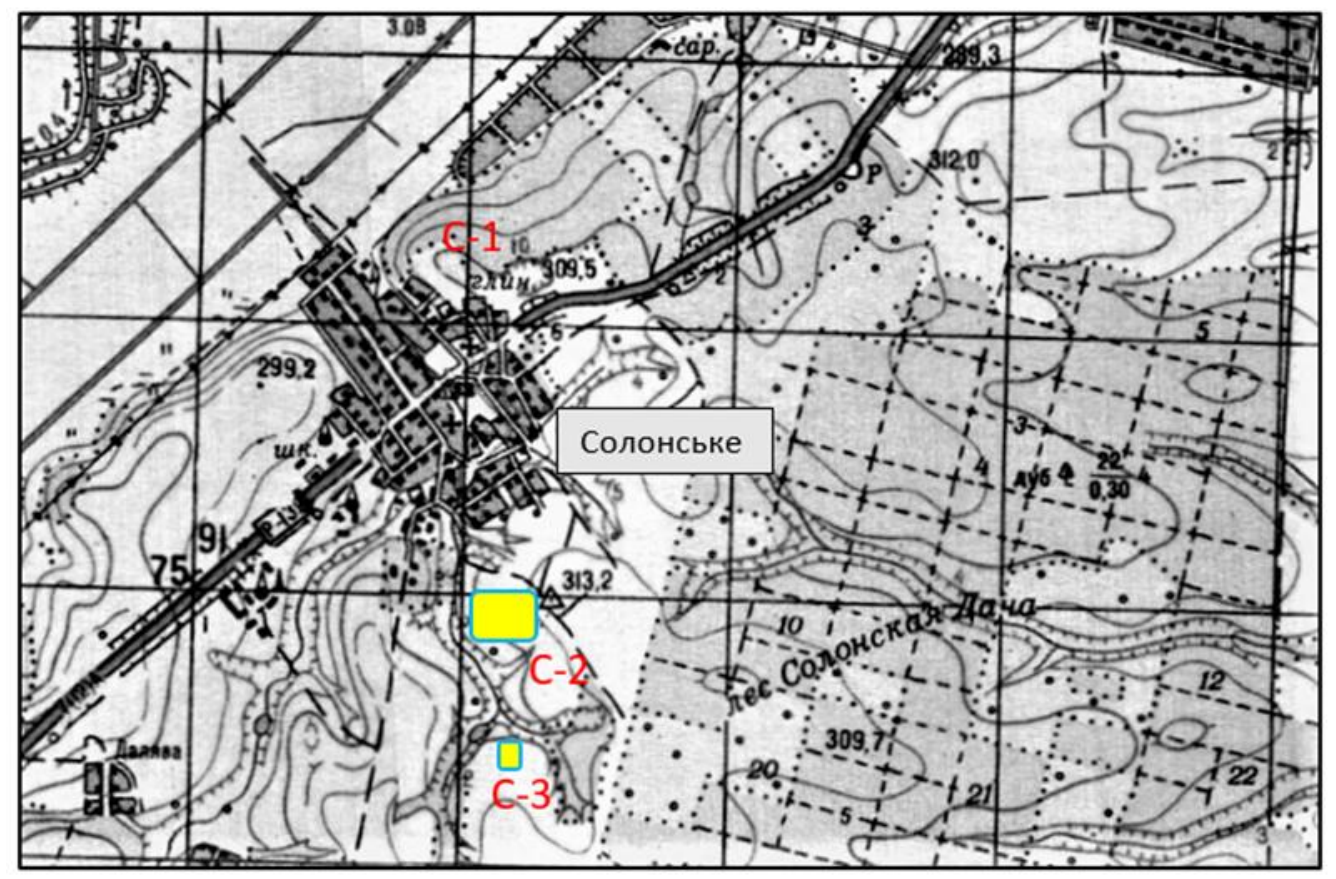

Рис. 1. Розташування розрізів Солонське 1-3 на топографічній карті.

Fig. 1. Location of Solonske sections 1-3 on the topographic map

У східній частині межиріччя Тисмениці-Стрию, де формування солонської тераси було пов'язане 3 р. Стрий (це засвідчує передусім відповідний загальний нахил iii поверхні), iï рівень можна простежити від краю Карпат до долини Дністра. На прикладі цієї ділянки легко виявити, що висота тераси над р. Стрий спочатку швидко спадає з віддаленням від гір (від 60 м біля с. Любинці до близько 30 м навпроти південної околиці м. Стрий), потім зниження поверхні тераси сповільнюється i, починаючи від району с. Ланівка, іiї висота повільно зростає. Ще далі до півночі - північніше с. Кавське, де максимальні абсолютні висоти тераси стабілізуються на рівні 300-302 м (тут і північніше солонська тераса є спільною для Стрию та Дністра), висота тераси починає швидко зростати і досягає 50-52 м над меженним рівнем Дністра. Терасу такої відносної 
висоти у Прибескидському Передкарпатті традиційно розглядають як п'яту (міндельську) надзаплавну терасу (Демедюк, 1986; Кравчук, 1999, с. 49).

Беручи до уваги морфологічні особливості чотирьох похованих грунтів, розкритих у товщі надгалечникових оглеєних лесів північного солонського кар'єру (розріз Солонське 1), М. Веклич зробив висновок про дещо молодший, завадівсько-дніпровський вік тераси; останню визначено також як п’яту надзаплавну терасу (Веклич, 1982). До групи середньонеоплейстоценових терас (нерозчленованої четвертої і п'ятої) зачислили іiі і автори державної геологічної зйомки (Герасімов та ін., 2005).

Суттєво інші уявлення про вікову приналежність солонської тераси представлені у статті, підготовленій працівниками ЛНУ імені Івана Франка (Богуцький та ін., 2016). Згідно із результатами їхніх досліджень, у головному кар'єрі с. Солонське розкрито утворення раннього, середнього та пізнього плейстоцену, у тому числі п'ять викопних грунтів, а алювіальна частина розрізу репрезентує будову одного із рівнів поверхні Лоєвої (шостої надзаплавної тераси Дністра).

Зведений розріз товщі терасових відкладів, стислий опис якого подано нижче, складений із окремих розчисток-розрізів, зроблених восени 2018 року головно у західній і центральній частинах відслонення Солонське 2. Західний фрагмент цього відслонення відповідає верхній частині схилу долини p. Ріпчанка, центральний і східний - прикрайовій частині вершинної поверхні, що представляє поверхню тераси. Остання біля брівки кар'єру розміщена на висоті 310-313 м, близькій до максимальної висоти (близько 315 м) солонської тераси у районі с. Солонське. У відслоненні Солонське 3, приуроченому до схилу долини (див. рис. 1), брівка кар'єру розміщена значно нижче. Як наслідок, у цьому кар'єрі відсутні два верхні шари (другий і третій), визначені у головному розрізі.

Основні результати дослідження. У товщі терасових відкладів, що розкрита в солонських кар'єрах, під сучасним (експонованим) грунтом можна виокремити щонайменше вісім шарів, потенційно важливих для іiі стратиграфії. Усі ці шари залягають майже горизонтально - без видимого загального нахилу до долини Ріпчанки або в іншому напрямку і знаходяться в певних інтервалах абсолютної висоти. Тому у відслоненнях, приурочених до схилів (розріз Солонське 3, західний фрагмент головної стінки розрізу Солонське 2), можна бачити, як експонований грунт або штучний зріз, здійснений більш-менш паралельно до його поверхні, послідовно зрізає шари верхньої частини товщі терасових відкладів - так званої лесово-грунтової серії, виокремленої нашими попередниками (Богуцький та ін., 2016).

Основу надгалечникової частини розрізу тераси творять шари безкарбонатних суглинків і глин, більшою чи меншою мірою оглеєних та озалізнених. Між ними розміщені два горизонти похованих грунтів. Верхній із них представлений комплексом із трьох грунтів, нижній - одним похованим грунтом. Назви деяких шарів (2-го, 3-го, 5-го), виокремлених у складі “лесовогрунтової серії” зведеного солонського розрізу тераси, доволі умовні.

1. Сучасний грунт $(0,0-1,6 / 1,9$ м) лісового генезису. Грунт вивчено в двох розчистках, зроблених у середній частині головної стінки розрізу Солонське 2 
біля краю вершинної поверхні, що представляє поверхню тераси. Профіль грунту у цій частині кар'єру поділений на горизонти:

- HE(gl) (0-23 см) - гумусово-елювіальний: світло-сірий, зі слабким бурим відтінком, легкосуглинковий, тонкопористий, $з$ незначною кількістю білястої присипки $\mathrm{SiO}_{2}$, наявні $\mathrm{Fe}-\mathrm{Mn}$ пунктуації та червоточини; перехід ясний, хвилястий;

- Ehgl (23-40 см) - елювіальний слабкогумусований: білувато-сірий, зі слабким бурим відтінком, легкосуглинковий, порохувато-плитчастий, тонкопористий; наявні червоточини, інтенсивна присипка $\mathrm{SiO}_{2}$, рясні $\mathrm{Fe}-\mathrm{Mn}$ пунктуації і бобовини; перехід ясний;

- EIgl (40-55 см) - елювіально-ілювіальний: сірувато-бурий з білуватими плямами, середньосуглинковий, горіхувато-призматичний, щільний, тріщинуватий; уздовж тріщин біляста присипка $\mathrm{SiO}_{2}$, наявні темно-бурі гумусово-глинисті кутани, Fe-Mn бобовини менш рясні; перехід ясний;

- Itgl (55-155/160 см) - ілювіально-текстурний: жовтувато-бурий, з білястосизими прожилками та сизувато-бурими плямами оглеєння, важкосуглинковий, грубопризматичної і брилуватої структури, дуже щільний, тріщинуватий; наявні глинисті кутани на стінках призм і тріщин та залізисто-манганові стяжіння; перехід поступовий;

- PIgl/F (155/160-195 см) - горизонт сильно ілювійованої материнської породи з ознаками фраджипену: світло-бурий до жовтого із сизуватим відтінком i бурувато-сизими прожилками, важкосуглинковий, призматично-брилуватий, розбитий транзитними вертикальними тріщинами; дуже щільний у сухому стані і крихкий у вологому; наявні $\mathrm{Fe}-\mathrm{Mn}$ пунктуації і бобовини; нижній контакт хвилястий, виразність і потужність горизонту помітно змінюються за простяганням.

На нерозчищеній поверхні відслонення для верхньої частини грунтового профілю характерний бурий наліт. Нижня частина грунту (ілювіальний горизонт разом із ілювійованою материнською породою) розбита крупними тріщинами, на стінках яких наявні колоїдні натіки, які мають сизе забарвлення у вологому стані i темно-буре - у сухому. Деякі з цих тріщин простежуються аж до основи наступного шару.

Морфологічні ознаки описаного грунтового профілю засвідчують його приналежність до текстурно-диференційованих профільно-оглеєних грунтів, фонових для Передкарпатської височини. Класифікаційна, номенклатурна та генетична ідентифікація цих грунтів є предметом тривалих наукових дискусій (напр., Паньків, Позняк, 1998; Польчина, 2012; Польчина, 2013). За визначенням одного із авторів статті діагностований грунт дерново-підзолистий глеюватий безкарбонатному лесоподібному суглинку.

2. Верхній горизонт оглесних лесоподібних суглинків $(1,95-4,75$ м) суглинки бурувато-палеві та буруваті, з сизими плямами оглеєння та смужками озалізнення, добре помітними у середній і нижній частинах шару (рис. 2);

\footnotetext{
${ }^{1}$ На думку С. Польчиної (Польчина, 2012; Польчина, 2013), профільно-диференційовані оглеєні грунти Українського Передкарпаття займають перехідне положення між дерново-підзолистими та бурими лісовими грунтами і є гетерогенними утвореннями, тому зачисляти ці грунти до типу буроземів або дерново-підзолистих грунтів не доцільно.
} 
Р. Гнатюк, І. Папіш. Солонський розріз...
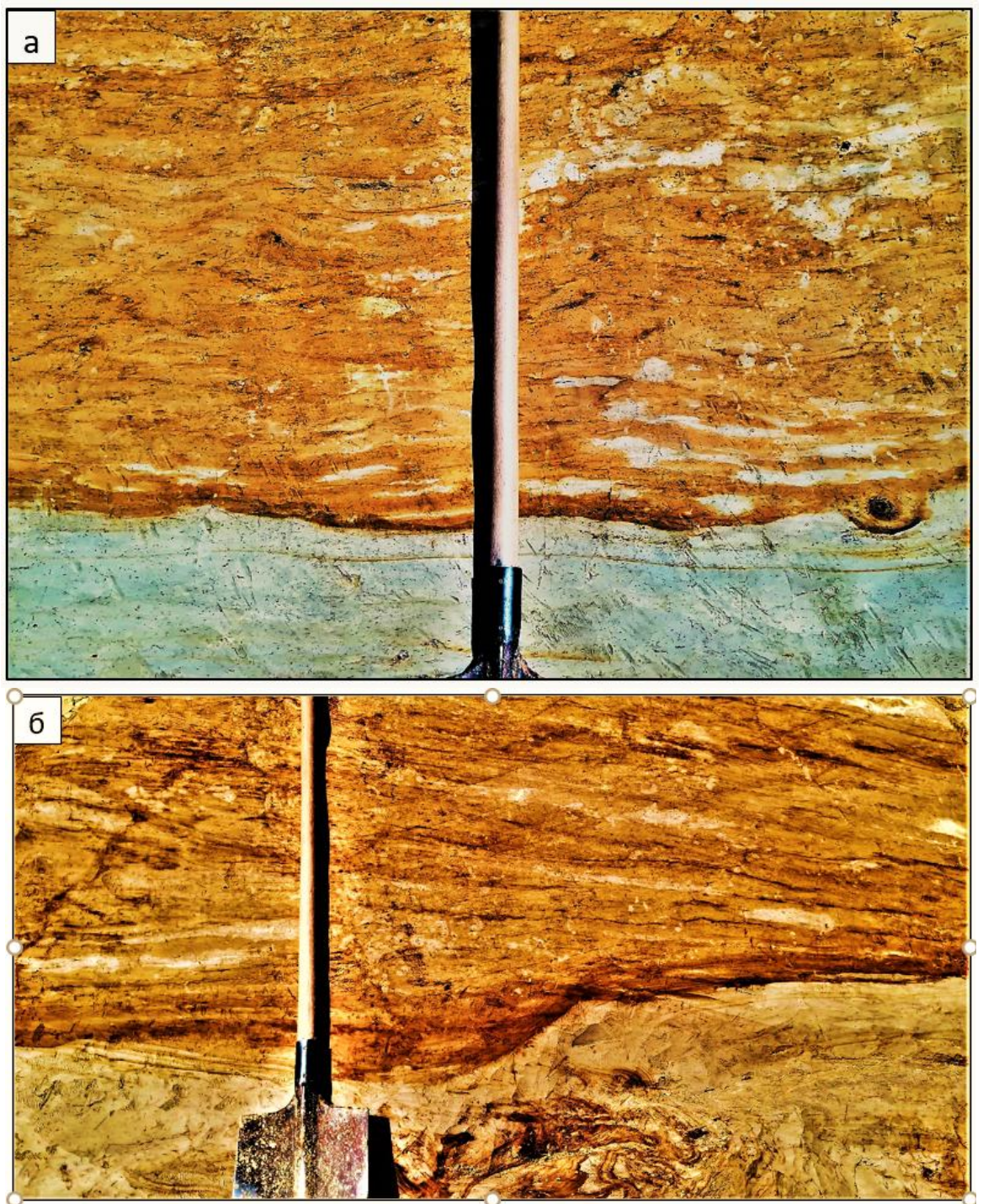

Рис. 2. Вигляд нижньої частини розрізу верхнього горизонту

оглеєних суглинків та його контакт з верхнім глейовим горизонтом

Fig. 2. View of the lower section of the upper horizon

of gleyed loams and its contact with the upper gley horizon

наявні численні залізисто-манганові стяжіння, здебільшого чорні й дрібні. Поблизу покрівлі і у середній частині шару суглинки легкі, сизувато-палеві та жовтуваті, лесоподібні. Суглинки середньої частини розрізу місцями близькі до супісків, порівняно слабко оглеєні і невиразно шаруваті (шаруватість унаочнена тонкими смужками озалізнення). Для нижньої частини розрізу властиві смужки, збагачені залізом і манганом. Смуги озалізнення місцями мають виразний нахил $i$ проникають у нижче розміщений глейовий горизонт, утворюючи мульдоподібні структури (див. рис. 2, б). 
У горизонт проникають вертикальні тріщини, пов'язані $з$ денним грунтом. Його потужність досить витримана i, зазвичай, коливається від 2,8 до 2,9 м. Перехід до наступного шару ясний і різкий за забарвленням.

3. Верхній глейовий горизонт $(4,75-7,10$ м) - суглинки здебільшого сизуватого, сизого та сизувато-темно-палевого кольору, 3 іржавими хвилястими смужками озалізнення різної виразності та товщини (рис. 3), місцями зі значною
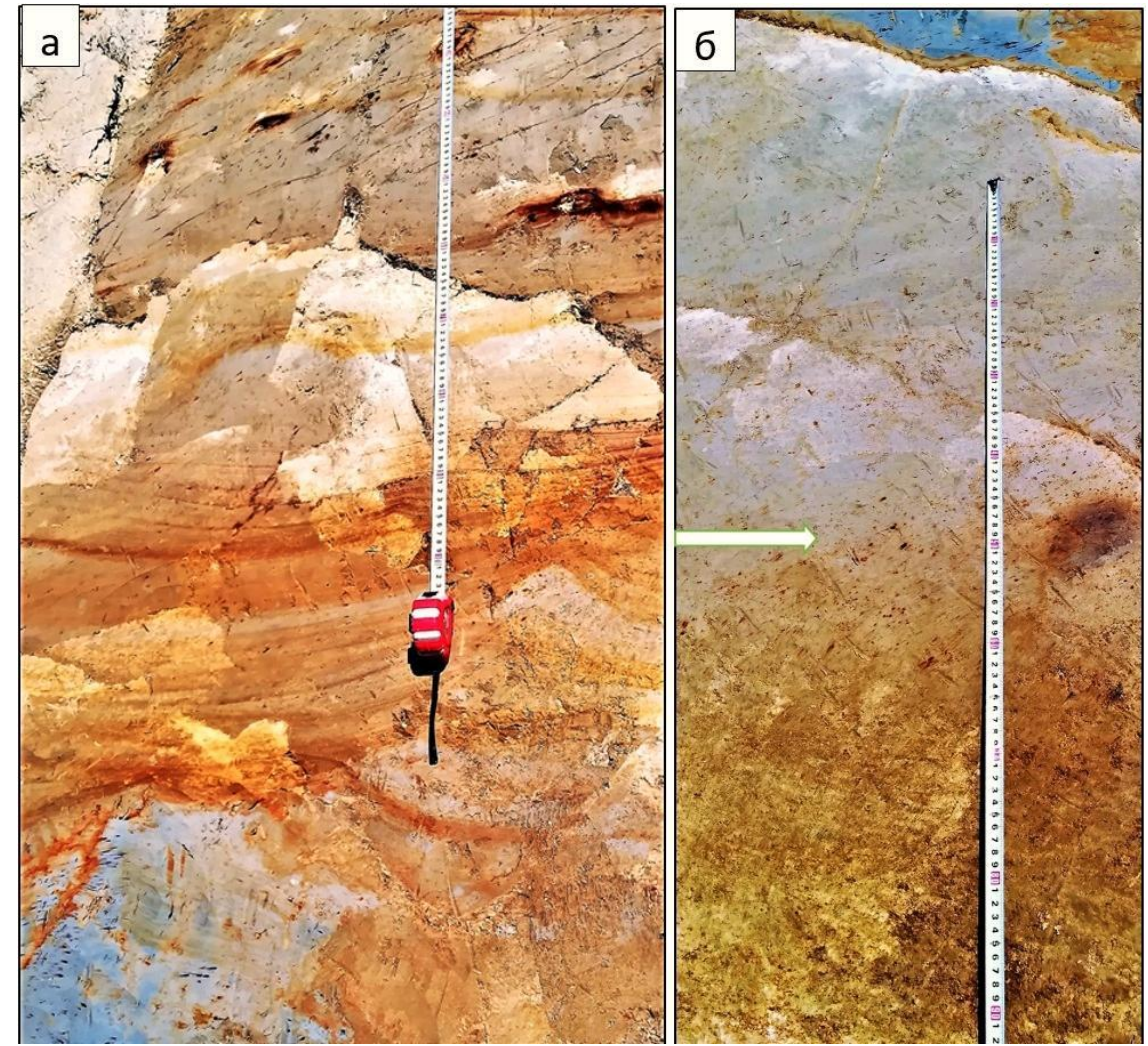

Рис. 3. Вигляд середнього (a) та нижнього (б) інтервалів розрізу верхнього глейового горизонту та його поступовий перехід у бурий лісовий грунт (білою стрілкою позначено положення невиразної межі глейового горизонту та грунту) Fig. 3. View of the middle $(a)$ and lower $(b)$ intervals of the section of the upper gley horizon and its gradual transition to the brown forest soil (the white arrow indicate the position of the indistinct boundary of the gley horizon and the soil)

концентрацією бурих залізистих стяжінь; трапляються темні прошарки, збагачені манганом, крупні плями та конкреції іржавого кольору типу кілець Лізеганга. Piвень оглеєності осаду та інші макроскопічні характеристики шару, зокрема, його товщина, помітно змінюються за простяганням відслонення. Місцями у його нижній частині наявні слабко оглеєні лесоподібні породи, схожі на породи 2-го горизонту.

У розрізі Солонське 2 , попри добру розкритість шару і підготовку розчисток на різних ділянках глинища, закономірних змін у його вертикальному зрізі виявити не вдалося. Натомість у різних частинах цього відслонення виявлено 
обкатані, частково обкатані та гострокутні уламки (дрібна галька, жорства, гравій) карпатських порід. Зауважено, що уламки частіше трапляються у нижній частині шару і виявляють приуроченість до основи його розрізу (рис. 4, 5). Місцями вони фактично фіксують положення поверхні давнього грунту, що підстеляє глейовий шар.

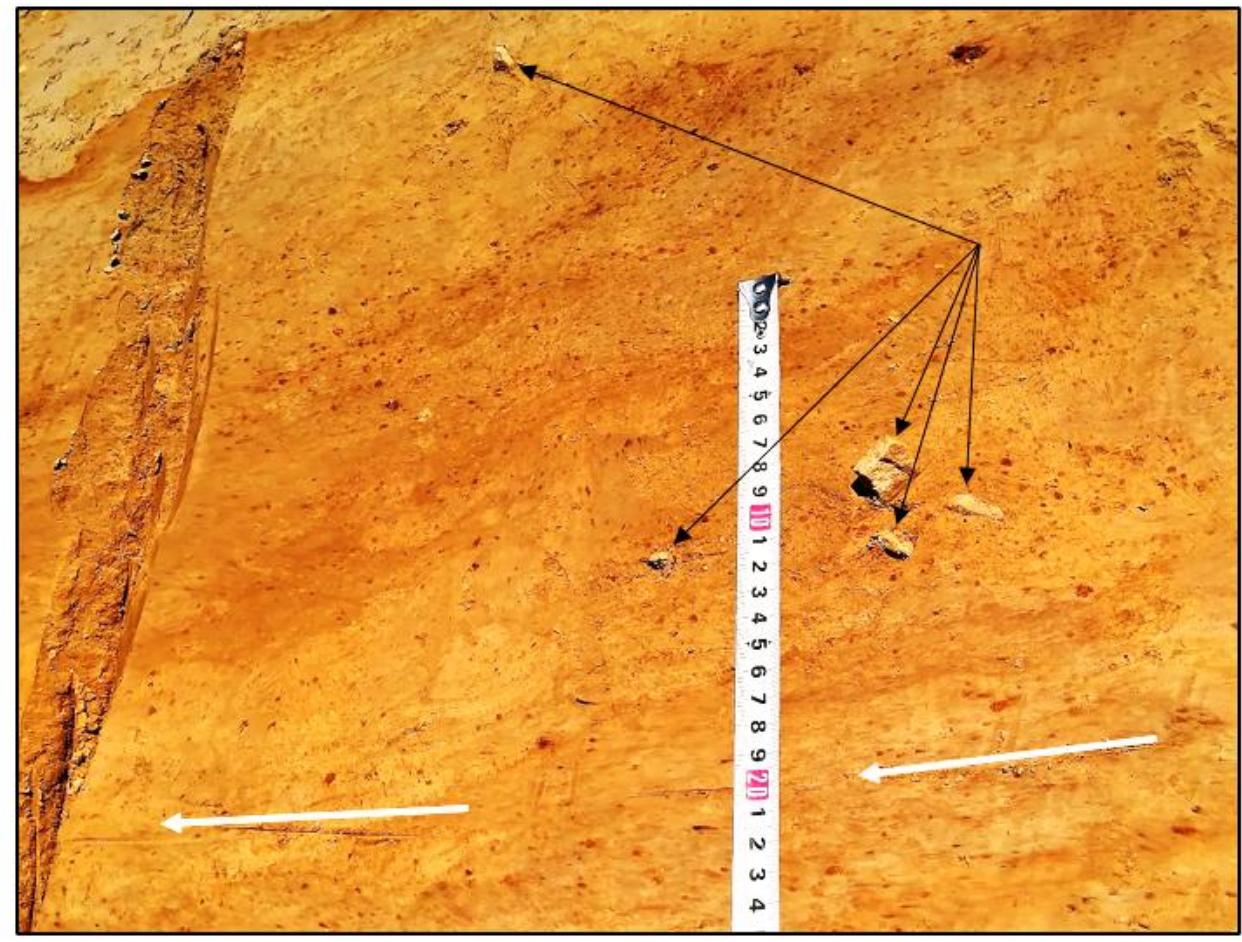

Рис. 4. Уламки карпатських порід у нижній частині верхнього глейового горизонту та його поступовий перехід у викопний грунт

(білими стрілками позначено положення невиразної верхньої межі грунту)

Fig. 4. The fragments of Carpathian rocks in the lower part of the upper gley horizon and its gradual transition to the fossil soil

(white arrows indicate the position of the upper boundaries of the soil)

Потужність глейового горизонту змінюється від 2,35 м на центральному відрізку стінки до 2,95 м у їі західній частині, де горизонт поступово “зрізається" схилом. Перехід до викопного грунту четвертого шару, зазвичай, поступовий i проявляється за сукупністю кількох ознак (з'являється оструктуреність, не властива глейовому горизонту, забарвлення стає мозаїчнішим і менш сизуватим/сизим, збільшується макропористість породи, зростає концентрація $\mathrm{Fe}-\mathrm{Mn}$ стяжінь). Контакт шарів місцями підкреслений смужкою озалізнення. Але частіше інтенсивне епігенетичне оглеєння та озалізнення їхньої приконтактної області призводить до утворення візуально дуже виразної хвилястої межі, яка не відповідає первинному контакту шарів, приуроченому до покрівлі похованого грунту. 
Хвиляста смугастість шару, властива різним інтервалам його вертикального розрізу (див. рис. 3), є наслідком міграції речовини, стимульованої глейовим процесом.

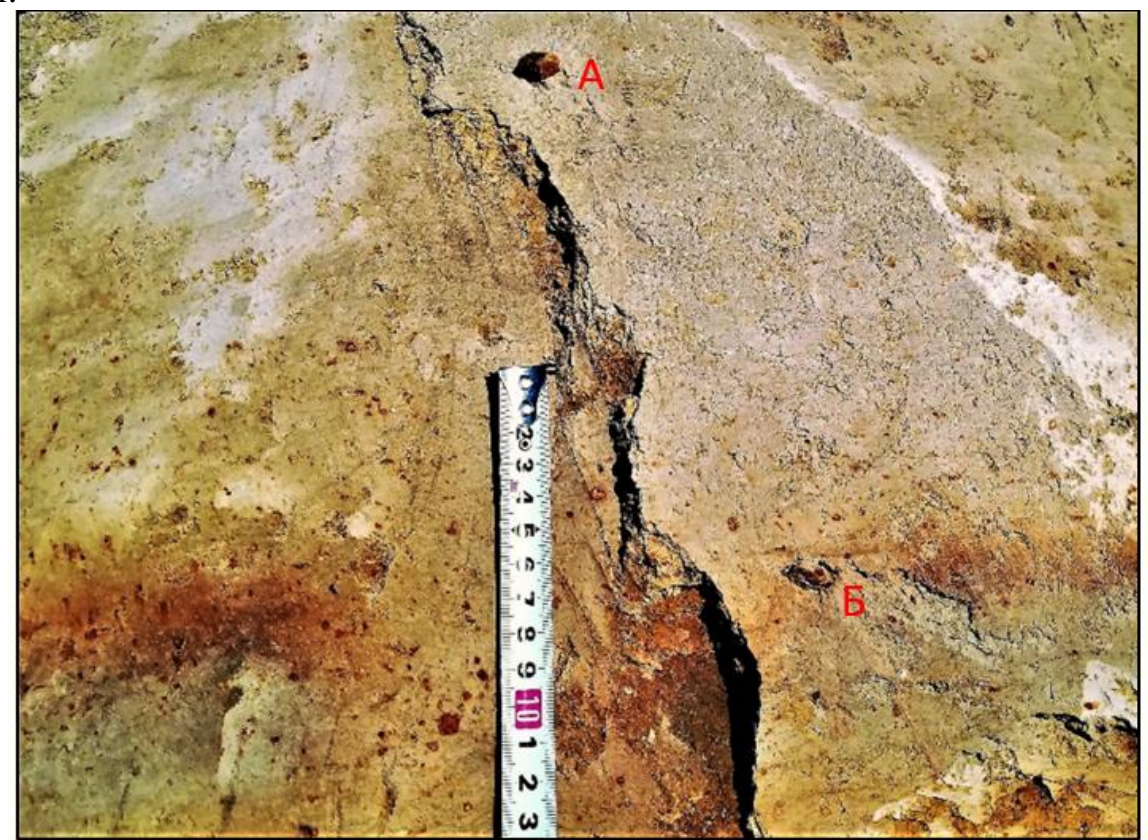

Рис. 5. Уламки карпатських порід у нижній частині верхнього глейового горизонту (А) та біля його межі з викопним грунтом (Б).

Фрагмент розчистки, зображеної на рис. $6, a$.

Fig. 5. The fragments of Carpathian rocks in the lower part of the upper gley horizon (A) and near its boundary with fossil soil (B).

The fragment of the cut which is depicted in Fig. 6, $a$.

4. Комплекс із трьох викопних грунтів (7,1-12,1 м). Два верхні викопні трунти (ВГ) комплексу фактично утворюють грунтову світу, яку розділити на окремі грунти без закладання масштабних розчисток буває проблематично, і у морфолого-генетичному плані вони подібні. Їх визначено як зрілі грунти буроземного типу (бурі лісові) зі слабко диференційованим профілем. До групи буроземних грунтів можна зачислити і менш гідроморфну відміну порівняно слабко розвиненого нижнього ВГ. Останній відокремлений від світи верхніх грунтів малопотужним (до 0,5-0,6 м) шаром більш чи менш оглеєних суглинків, місцями виразно смугастих. Потужність грунтового комплексу сягає 5,0 м.

Верхній ВГ (nідгоризонт 4.1) має помітні ознаки текстурної диференціації грунтового профілю, у його верхній частині місцями видно присипку $\mathrm{SiO}_{2}$. Гумусово-елювіальний горизонт (0-25 см) ВГ, зазвичай, вирізняється великою кількістю залізистих і залізисто-манганових стяжінь. Ілювіальний горизонт жовтувато- й іржаво-бурий, без виразної верхньої межі (рис. $6, a$ ), глинистий, горіхуватозернистої структури, з розвиненою міжагрегатною макропористістю; для горизонту властиві темно-бурі залізисто-глинисті кутани та субвертикальні білястосизі та сірі прожилки. Материнська ілювійована порода вгорі (110-140 см) темно-бура, 3 сизими та іржаво-бурими плямами, глиниста, горіхувато- 
Р. Гнатюк, І. Папіш. Солонський розріз...

брилуватої структури, містить глинисті натьоки на стінках тріщин. Низ материнського горизонту, представлений слабко оструктуреними та безструктурними суглинками (140-165 см), має мозаїчне сизувато-буре забарвлення 3 крупними сизими плямами. Зазначені макроскопічні ознаки ВГ засвідчують його приналежність до групи підзолисто-буроземних глеюватих грунтів.

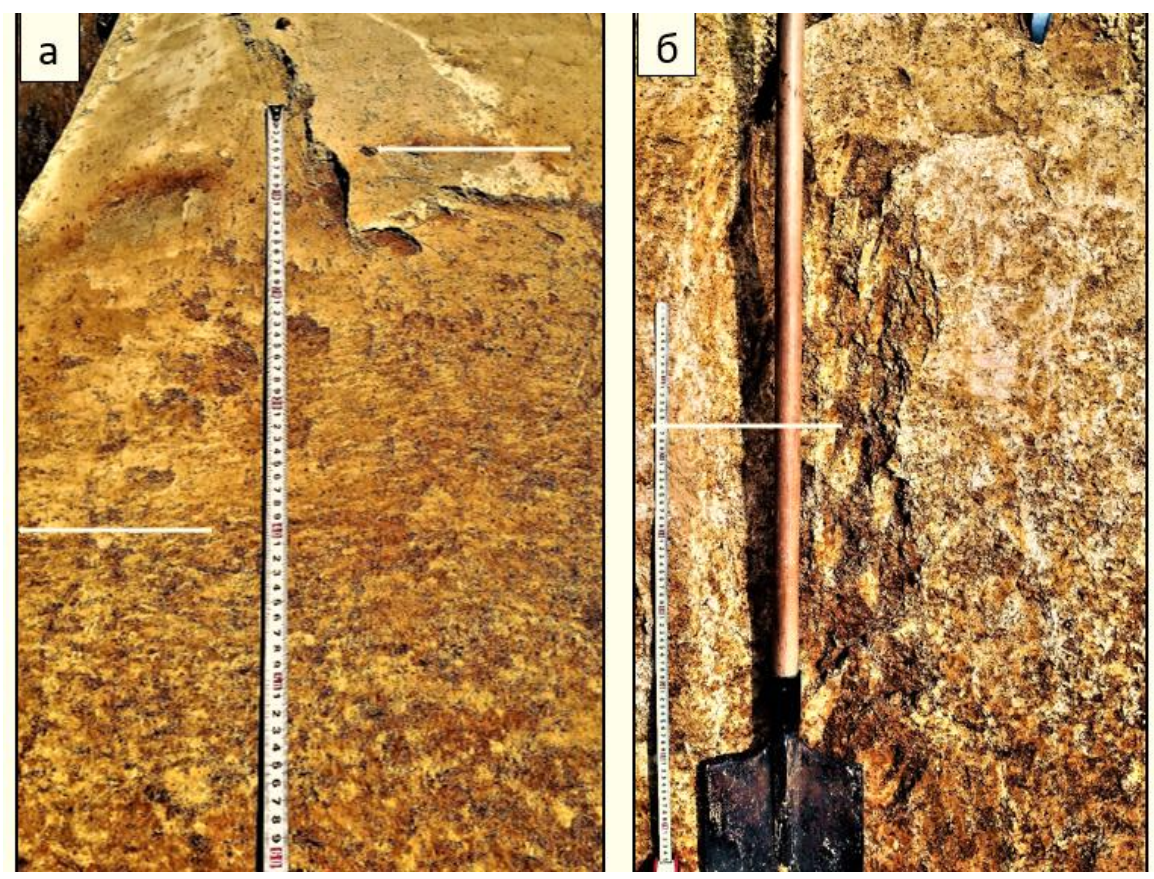

Рис. 6. Верхня частина верхнього викопного грунту (підгоризонту 4.1): $a$ - порівняно слабко оглеєного; $\sigma$ - порівняно сильно оглеєного (білими стрілками позначено положення верхньої межі грунту та його ілювіального горизонту)

Fig. 6. Upper part of the upper fossil soil (subhorizon 4.1): $a$ - relatively weak gleyed; $\sigma$ - relatively strongly gleyed (white arrows indicate the position of the upper boundary of the soil and its illuvial horizon)

У кар'єрі Солонське 2 верхній ВГ найліпше відслонений 3-поміж усіх інших грунтів комплексу. Завдяки закладанню у західній і центральній частинах головної стінки кар'єру багатьох розчисток з'ясовано, що вигляд цього ВГ на різних ділянках відслонення різний (див. рис. 6) і визначається насамперед рівнем його син- $\mathrm{i} /$ чи постпедогенного оглеєння та озалізнення. Зокрема, існує певний зв'язок між рівнем оглеєння ВГ та виразність диференціації його грунтового профілю - на ділянках порівняно значного оглеєння та постпедогенної окислювальної сегрегації особливо виразно виокремлюється верхній, гумусово-елювіальний горизонт, насичений залізисто-мангановими стяжіннями. Верхня частина (до глибини 0,4 м) ВГ у таких місцях порівняно слабко агрегована, місцями смугаста - як і низ покривного глейового горизонту, містить присипку $\mathrm{SiO}_{2}$; в ілювіальному горизонті з'являються сизувато-білясті вертикальні прожилки, обмежені смужками озалізнення, i він набуває 
Р. Гнатюк, І. Папіш. Солонський розріз...

строкатого, мармуроподібного забарвлення (див. рис. 6,б). Характерно, що простягання смужок оглеєння й озалізнення у смугастому різновиді грунту змінюється із субгоризонтального у його гумусово-елювіальному горизонті до субвертикального в ілювіальному. Місцями (рис. 7) найпомітніші глейові прошарки верхньої частини грунтового профілю безпосередньо змикаються із субвертикальними прожилками його ілювіального горизонту. Нормальна будова грунтового профілю в таких місцях порушена постпедогенною дефлюкцією (повільною соліфлюкцією).

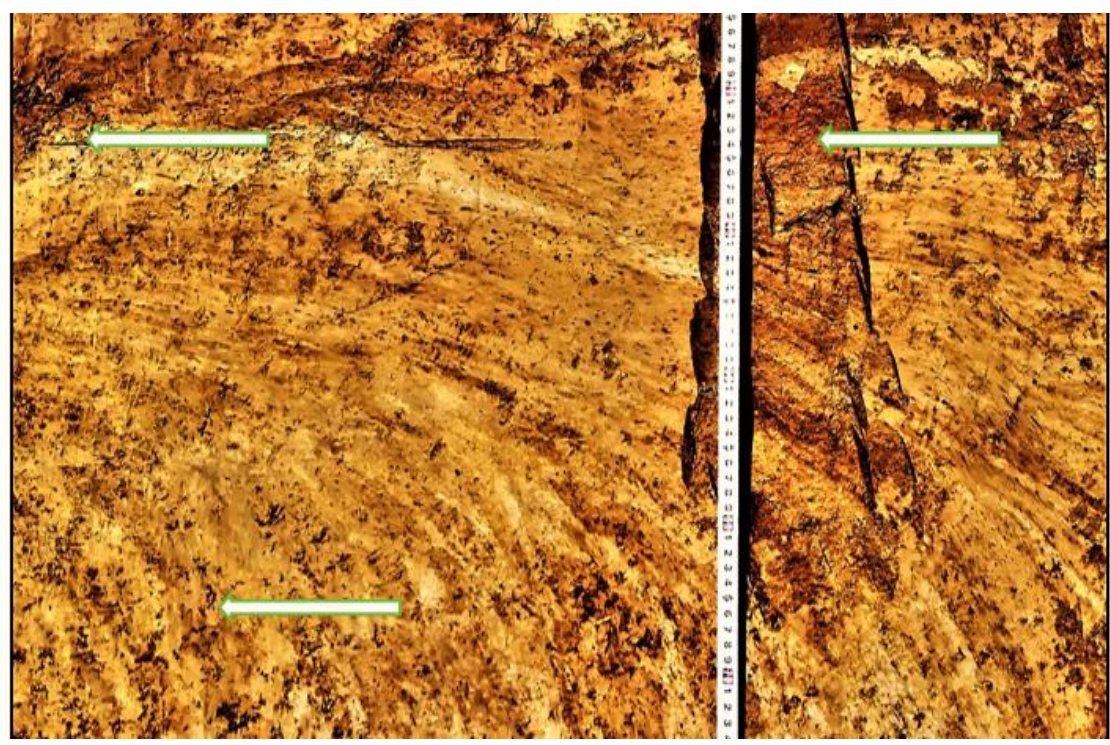

Рис. 7. Верхня частина верхнього викопного грунту, порушена внаслідок постпедогенної дефлюкції (білими стрілками позначено положення верхньої межі грунту та його ілювіального горизонту)

Fig. 7. The upper part of the upper fossil soil, dislocated as a result of postpedogenic defluction (white arrows indicate the position of the upper boundary of the soil and its illuvial horizon)

У верхній і середній частинах грунтового профілю трапляються уламки карпатських порід.

Cередній ВГ (підгоризонт 4.2) схожий до попереднього, але не має ознак опідзолення. Його приповерхнева частина (слабко виражений гумусовоелювіальний горизонт) також буває смугастою; смуги місцями утворюють концентрично-овальні форми складної конфігурації. Для середини й низу грунтового профілю характерні виразні білясто-сизуваті прожилки (зони оглеєння та відбілювання), обмежені іржаво-бурими смужками (зонами залізоглинистого насичення), менш помітними на жовтувато-бурому тлі ВГ (рис. 8).

Такі специфічні, з огляду на особливу виразність, утворення цього грунту засвідчують інтенсивне перенесення оксидів заліза і глинистих мінералів уздовж тріщин. Останні бувають нахиленими та субвертикальними. Обидва типи тріщин розпочинаються в межах ВГ безпосередньо біля верхньої межі його ілювіального горизонту. 
Потужність ВГ сягає 1,7 м.

Нижній ВГ (підгоризонт 4.4) розкритий у двох розчистках, зроблених у центральній частині відслонення Солонське 2. Попри близьку відстань між ними (близько 60 м) і більш-менш однакову потужність грунтового профілю $(1,2-$ 1,4 м), його вигляд у різних розчистках різний. Це засвідчує значну просторову неоднорідність давнього грунтового покриву.
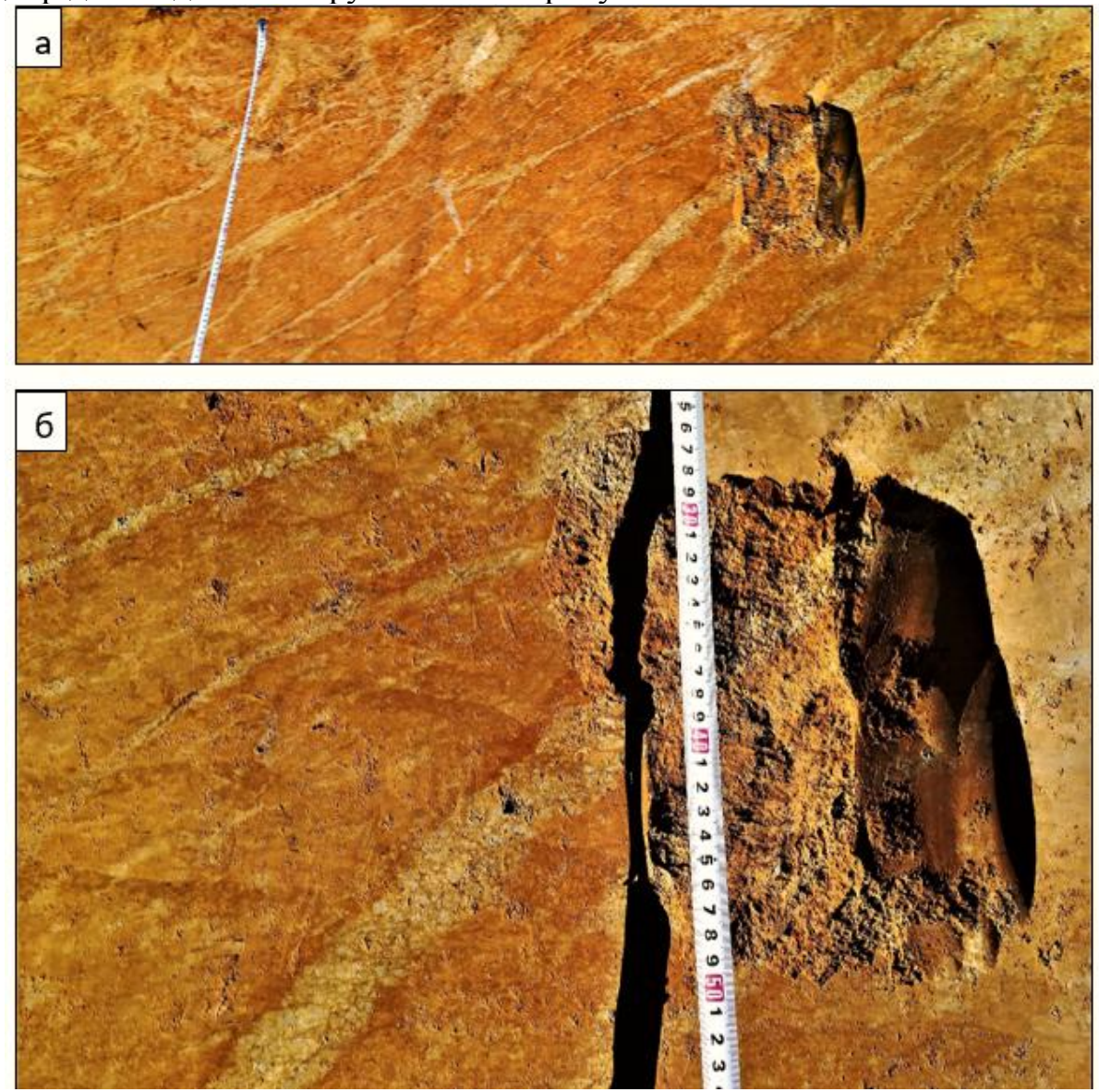

Рис. 8. Глейові прожилки в середній частині середнього викопного грунту (підгоризонту 4.2): розчистка (a) та їі фрагмент (б)

Fig. 8. Gley veins in the middle part of the middle fossil soil (subhorizon 4.2): clearing $(a)$ and its fragment $(b)$

У західній розчистці цього відслонення, розміщеній біля брівки сучасного схилу долини, грунт сильно оглеєний та озалізнений і поступово переходить у покривний підгоризонт 4.3. У межах його невиразно розчленованого профілю можна виокремити такі морфолого-генетичні горизонти:

- Hgl (0-30 см) - сизувато-бурий і темно-бурий із сизими плямами, сильно озалізнений, вологий, глинистий, щільний, брилувато-зернистої структури; характерні сизі плями сполук $\mathrm{Fe}_{2}{ }^{+}$та іржаво-бурі $\mathrm{Fe}-\mathrm{Mn}$ бобовини;

- PhGl (30-85 cм) - мармуроподібного забарвлення з крупними натіками й плямами іржаво-бурого озалізнення у верхній частині, внизу здебільшого сизува- 
Р. Гнатюк, І. Папіш. Солонський розріз...

тий, 3 іржаво-бурими плівками на стінках структурних агрегатів, вологий, глинистий; грудкувато-зернистої структури;

- GL (85-130 см) - сизий глей з нестійкими крупними агрегатами плитчастої форми, щільний, тугопластичний.

Грунт визначено як лучно-болотний залізистий.

У східній розчистці цей ВГ порівняно слабко оглеєний, із виразною покрівлею, яка різко відділена від плямисто-смугастого підгоризонту 4.3 i плікативно деформована разом з його різнобарвними оглеєними й озалізненими суглинками (рис. 9). Потужність підгоризонту 4.3 сягає тут 0,45 м і більше. У його межах поблизу розчистки наявні крупні включення-плями сильно оглесних (сизих) суглинків, які, згідно з описом авторів праці (Богуцький та ін., 2016) нагадують плями-медальйони. Подібні за формою кулясті включення більшменш однорідних суглинків у переважно смугастому підгоризонті 4.3 мають i сизувато-палевий колір (див. рис. 9). Сам ВГ у цьому місці відслонення схожий на грунт буроземного типу і принципово подібний до двох пізніше утворених ВГ четвертого шару. Лише його потужність $(1,2-1,3$ м) значно менша.

5. Нижній горизонт оглесних лесоподібних суглинків $(12,1-14,4$ м) - суглинки жовто-бурі та буруваті, із сизуватими розводами та плямами оглеєння різної величини, злиті, важкі, з численними чорними примазками і залізистомангановими стяжіннями.

Шар розбитий крупними вертикальними тріщинами, стінки яких вкриті дендритами чорного кольору. Через погані фільтраційні властивості він вирізняється також як найбільш зволожена товща верхньої частини розрізу головної стінки кар'єру Солонське 2.

Потужність горизонту у розрізі Солонське 2 коливається від 2,0 до 2,3 м. У розрізі Солонське 3 його товщина становить близько 2,1 м. Перехід до нижнього шару виразний і чіткий за забарвленням.

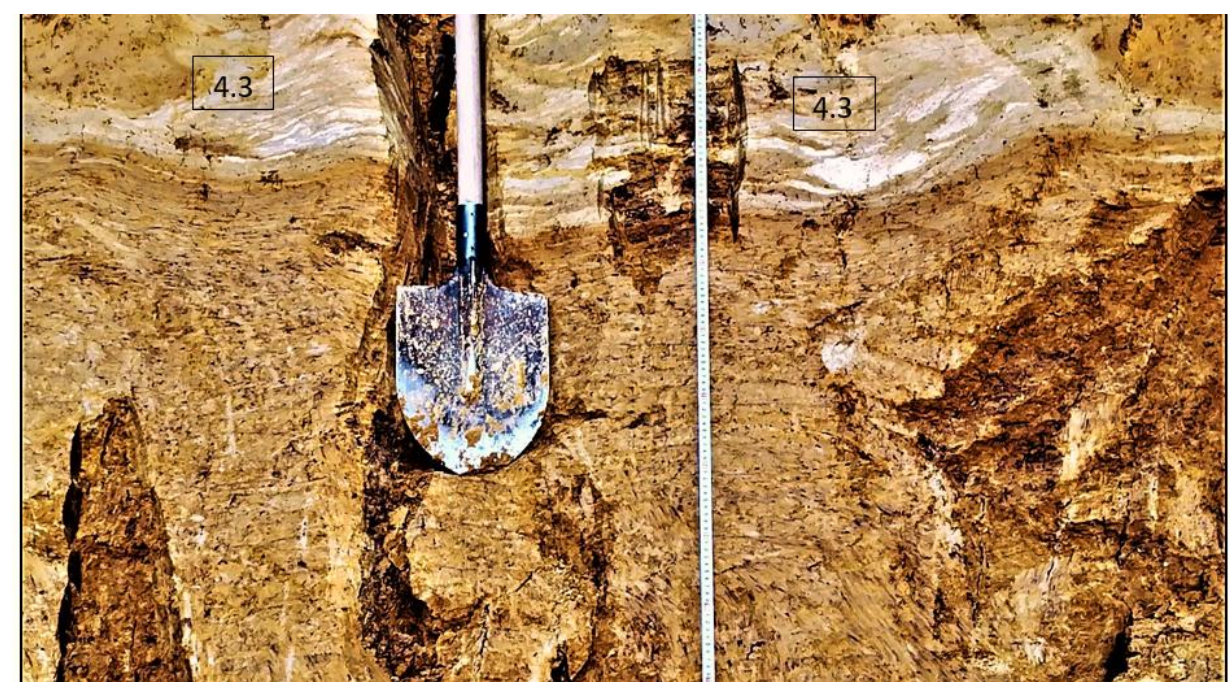

Рис. 9. Верхня частина нижнього викопного грунту (підгоризонту 4.4) і його контакт із підгоризонтом 4.3

Fig. 9. Upper part of the lower fossil soil (of the subhorizon 4.4) and its contact with the subhorizon 4.3 
Р. Гнатюк, І. Папіш. Солонський розріз...

6. Середній глейовий горизонт (14,4-17,3 м) - суглинки різнобарвні із перевагою сизого, сизувато-сірого та палево-сизуватого кольору, головно важкі, різною мірою оглеєні та озалізнені. Характерні виразні смуги епігенетичного озалізнення (рис. 10) й утворені ними плікативні псевдодеформації (псевдоструктури), властиві також і верхньому глейовому горизонту (див. рис. $3, a$ ). Подекуди трапляються крупні форми типу кілець Лізеганга. Усі ці утворення є наслідком глеєвої міграції речовин.

Горизонт найліпше відслонений у центральній частині великого солонського кар'єру. Тут його можна поділити на три підгоризонти приблизно однакової товщини: верхній - порівняно слабко оглеєний і легкий за гранулометричним складом; середній - суцільний важкосуглинистий чи глинистий тугопластичний глей, здебільшого сизого кольору; нижній - складений із сизувато-сірого та сіруватосизого тугопластичного глею. Щоправда, розмежувати два нижні шари місцями буває проблематично 2 .

У цьому ж кар'єрі поблизу покрівлі (до глибини 0,7 м) глейового горизонту подекуди спостерігається виразна шаруватість суглинистих відкладів, зумовлена наявністю лінз і лінзоподібних прошарків крупного пилу та тонкозернистого піску (рис. 11). В усіх місцях іï прояву фіксовано дрібну складчастість або осібно розміщені форми антиклінального типу, здебільшого шатроподібні.

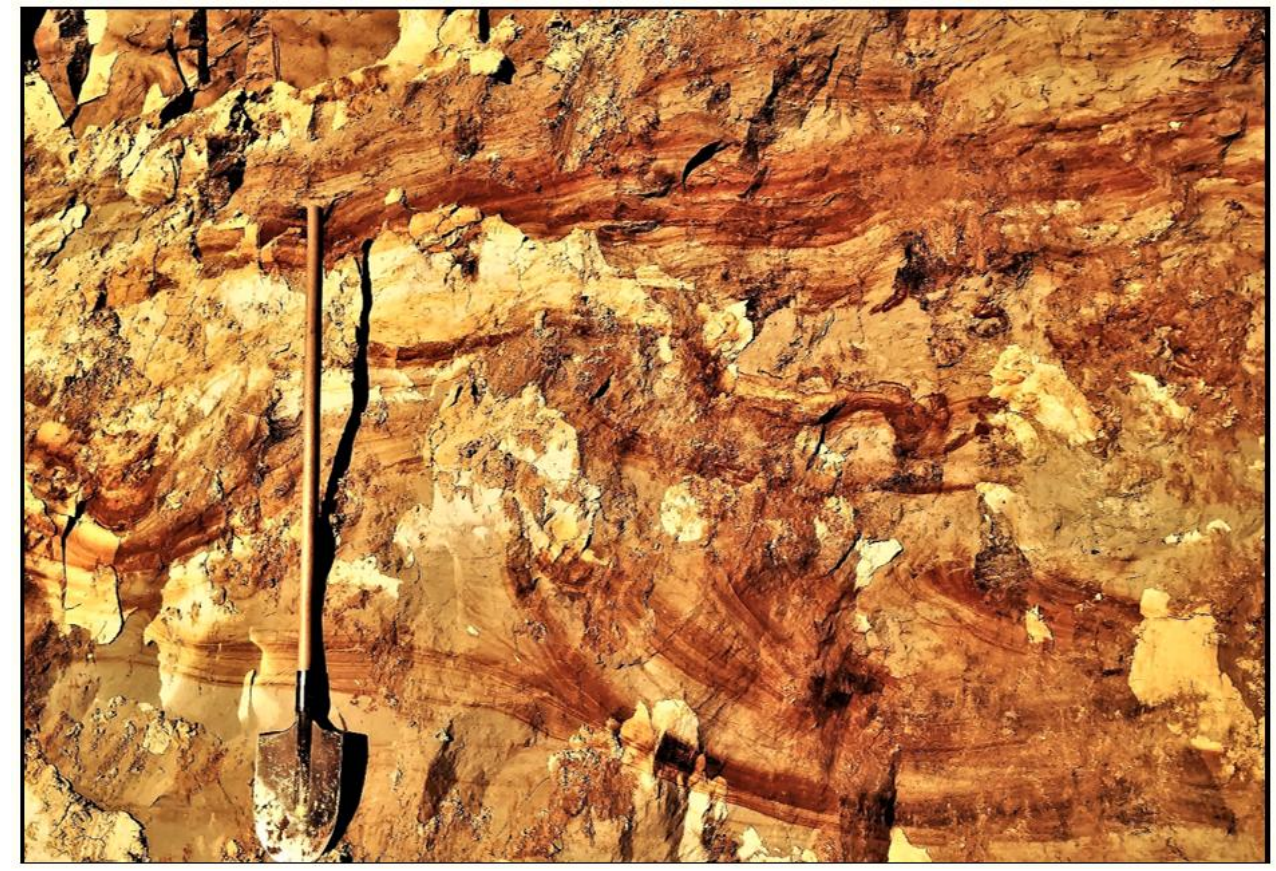

Рис. 10. Смуги озалізнення в середньому глейовому горизонті

Fig. 10. Strips enriched of iron compounds in the middle gley horizon

2 Відслонена поверхня горизонту під впливом атмосферного повітря поступово змінює своє забарвлення і з часом стає оливковою (на зволожених ділянках відслонення) або сизувато-білястою (в сухіших місцях). 


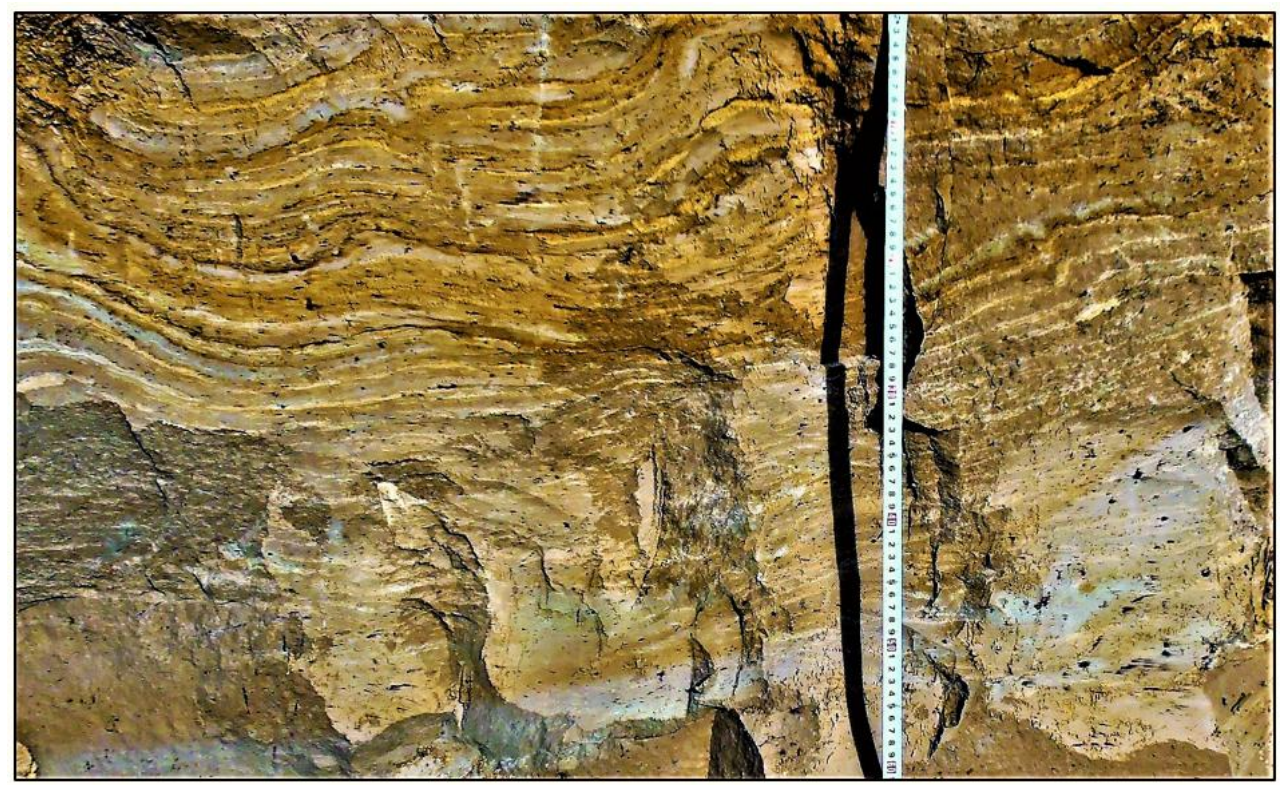

Рис. 11. Шаруваті суглинки у верхній частині середнього глейового горизонту Fig. 11. Laminated loams in the upper part of the middle gley horizon

У нижній частині горизонту - на рівні близько 0,4 м від його основи знайдено один частково обкатаний уламок (кременистий алевроліт сірого кольору), довжина довгої осі якого становила приблизно 7 см.

В центральній частині великого солонського кар'єру нижній контакт горизонту макрохвилястий, із довжиною “півхвиль” у кілька десятків метрів. Через хвилястість підошви шару його потужність у різних місцях цієї частини відслонення різна і змінюється від близько 2,8 м до 4,5 м.

$\mathrm{y}$ розрізі Солонське 3 горизонт принципово подібний i має порівняно незначну товщину $(2,75-2,80$ м); він теж сизувато-сірий у нижній частині.

Перехід до нижнього шару здебільшого чіткий.

7. Сірий глейовий грунт $(17,3-18,6$ м). Грунт помітно відрізняється від інших ВГ солонських розрізів завдяки специфічному сірому забарвленню верхньої частини грунтового профілю й наявності темно-сірого, майже чорного прошарку, що фактично фіксує його верхню межу (рис. 12). Він вирізняється також стабільністю ознак відновлювального глейового гідроморфізму, яка не властива для інших ВГ.

Зауважено, що прошарок темно-сірого кольору, приурочений до покрівлі ВГ, слабко розвинений або й відсутній в центральних частинах давніх піднять. У межах останніх власне і сам ВГ порівняно слабко розвинений. Підмічено також, що у місцях найліпшого розвитку темний прошарок має виразні межі і синій відблиск на гладкій поверхні розчистки, а безпосередньо під ним, зазвичай, добре видно смужку білуватого кольору, збагачену на присипку $\mathrm{SiO}_{2}$. Вміст гумусу у прошарку сягає $1,2 \%$; його потужність, зазвичай, не перевищує 5-6 см. Глиниста маса прошарку після висихання набуває бурого забарвлення. 
Зазначене дає підстави вважати, що формування темного прогумусованого прошарку зумовлене нагромадженням рослинних залишків на поверхні грунту (особливість грунтоутворення, характерна для лісових і заболочених грунтів), тому сам прошарок слід розглядати як органогенний, ймовірно, торф'янистоперегнійний горизонт ВГ.

У розрізі Солонське 3 під прогумусованим прошарком темно-сірого кольору визначено чотири горизонти ВГ, генетична інтерпретація яких видається наразі проблематичною:

1. HegI (0-12, місцями до 15 см) - сизувато-сірий зі слабким бурим відтінком, з численними білястими плямами кремнезему, розміри й концентрація яких зменшуються із глибиною, супіщано-суглинистий, слабко оструктурений i безструктурний. У верхній частині шару трапляються гнізда кремнезему. Перехід донизу помітний і поступовий;

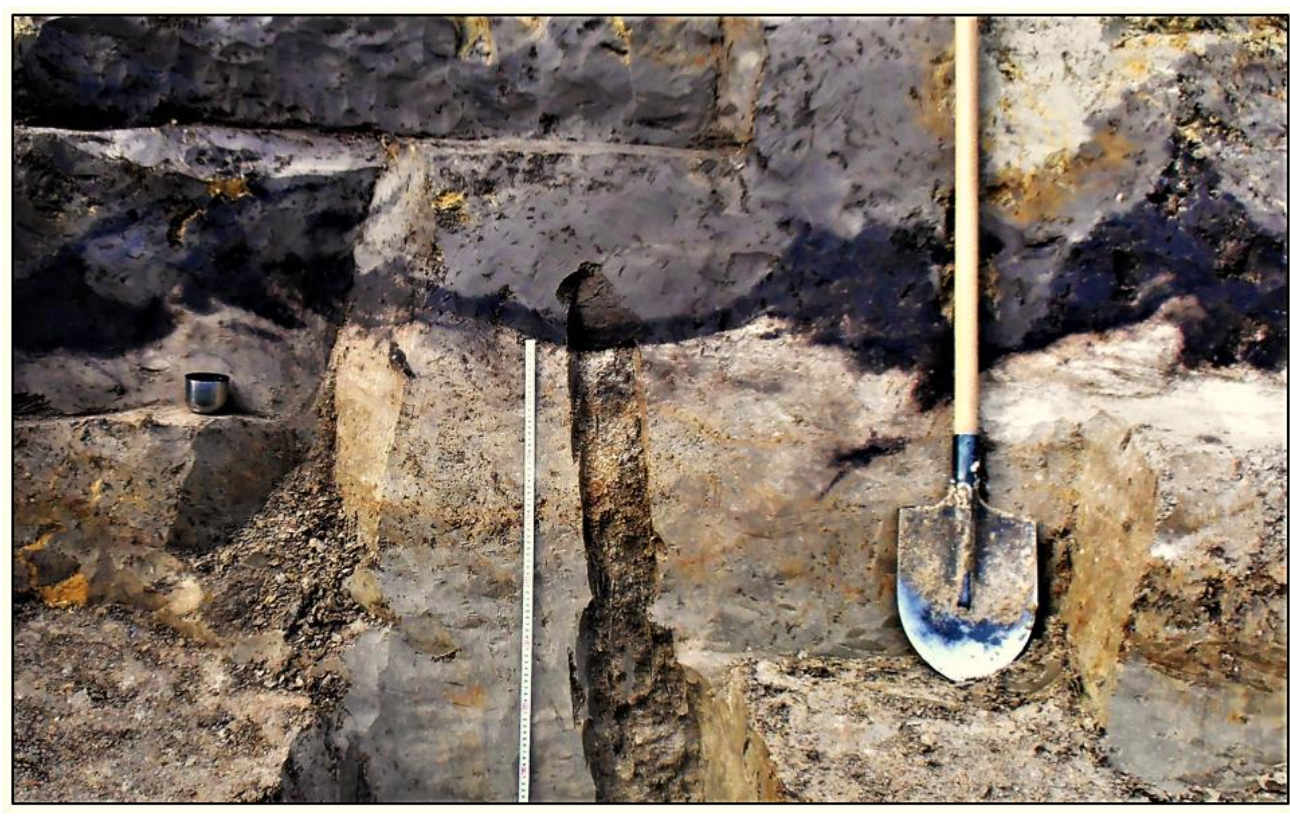

Рис. 12. Кріогенні деформації при контакті середнього глейового горизонту та сірого глейового грунту у розрізі Солонське 3

Fig. 12. Cryogenic deformations on the contact of the middle gley horizon and gray gley soil in the section Solonske 3

2. HPgl/Gl (12-35 см) - ліпше агрегований важкий суглинок, світліше забарвлений у верхній частині шару; характерні плями (структурні окремості) білястосизуватого кольору, а також розводи та плями іржаво-бурого озалізнення. Перехід поступовий;

3. PhGI (35-60 см) - слабко оструктурений сірувато-сизий суглинок 3 зернами сизого кольору, добре помітними на тлі поверхні структурних окремостей сизувато- та бурувато-сірого забарвлення; трапляються розводи та плями озалізнення, перехід поступовий; 
Р. Гнатюк, І. Папіш. Солонський розріз...

4. PGI (60-85 см і глибше) - світліше забарвлений суглинок, щільніший і гірше оструктурений (структура головно пластинчаста), порівняно з попереднім шаром. Бурий відтінок, властивий розміщеним вище шарам, відсутній.

У нижній частині грунтового профілю на гладкій поверхні розчистки видно текстури, найімовірніше, кріогенного типу, розміщені в певній послідовності від комірчастої у горизонті 3 до сітчастої та неповносітчастої в розкритому інтервалі нижнього горизонту. Аналогічні текстурні утворення у нижній частині цього ж ВГ можна бачити і в головному кар'єрі (розріз Солонське 2), де їхня наявність засвідчена раніше (Богуцький та ін., 2016). Зазначимо, що схожі текстури - від сітчастої до шаруватої - виявлено в різних інтервалах нижнього ВГ тричленного грунтового комплексу (рис. 13).

У розрізі Солонське 2 профіль глейового ВГ на ділянці його найліпшого розвитку принципово подібний. Без урахування торф'янисто-перегнійного горизонту у його межах можна виокремити три головні шари:

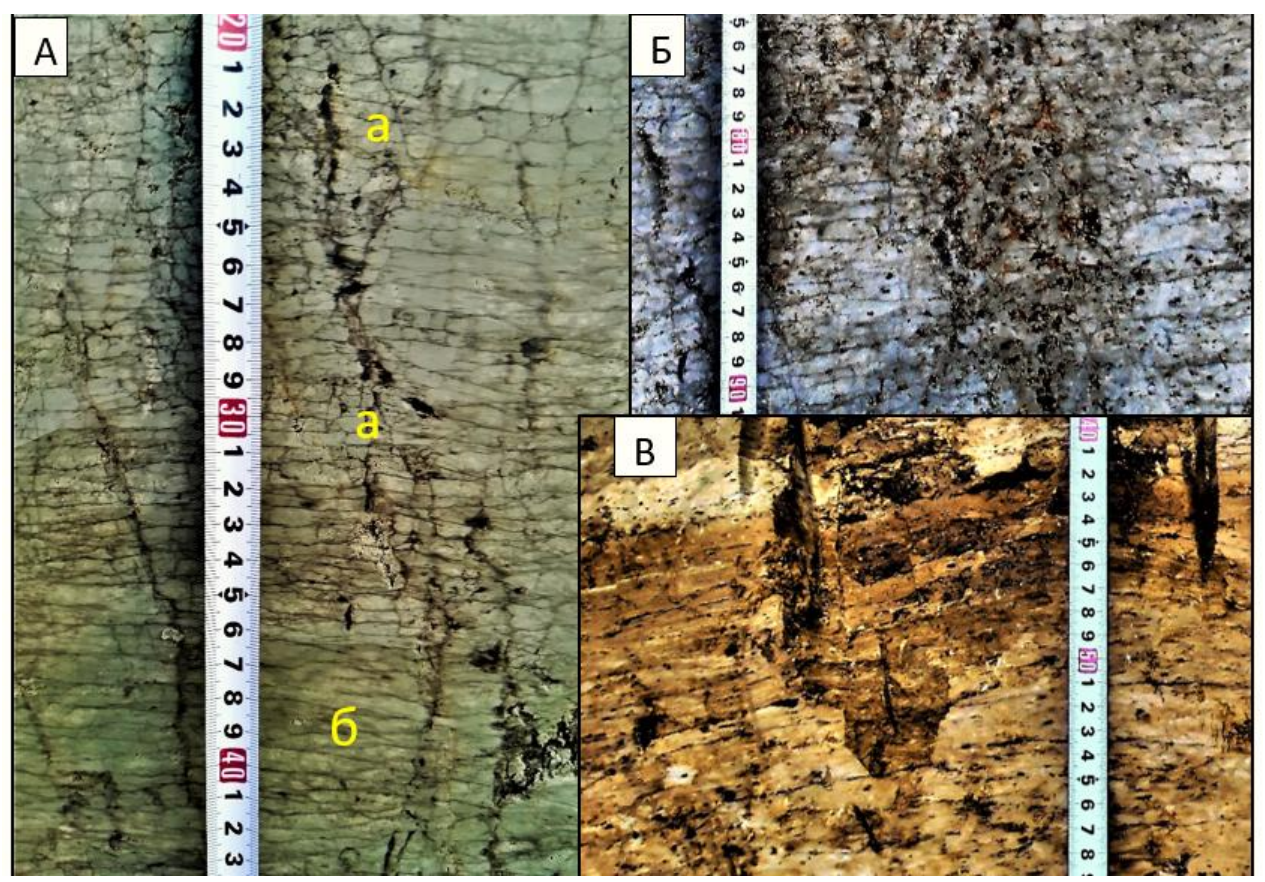

Рис. 13. Посткріогенні текстури у ВГ розрізу Солонське 2: А - неповносітчаста

(a) і сітчасто-шарувата до шаруватої (б) у нижній частині сірого глейового грунту; Б - сітчасто-шарувата в середній частині нижнього викопного грунту

(підгоризонту 4.4) у його гідроморфній фації; В - шарувата при покрівлі нижнього викопного грунту у його автоморфній фації

Fig. 13. Post-cryogenic textures in the paleosols of the section Solonske 2:

A - in the lower part of gray gley soil; B - in the middle part of the lower fossil soil

(subhorizon 4.4) in its hydromorphic facia; $\mathrm{C}$ - near the upper limit of the lower fossil soil in its automorphic facia

- Hgl товщиною від 20 см до 30-35 см (значні коливання товщини пов'язані 3 деформованістю верхньої частини ВГ) - сизувато-сірий у вологому стані і білясто-сірий у сухому, місцями зі слабким бурим відтінком, слабко 
оструктурений і безструктурний, зі світлими зернами оглеєння, наявність яких зумовлює комірчасту текстуру породи, виразнішу у нижній частині шару;

- HPgl,Gl (20/35-60/70 cм) - у верхній частині плямисто забарвлений з численними плямами (зернами) сизуватого кольору на сірому та бурувато-сірому тлі; у нижній частині шару оглеєні структурні окремості починають творити його тло; характерні тонкі переривчасті смужки іржавого озалізнення, виразно проявлені комірчаста (верх) та сітчаста (низ) текстури;

- PhGl (60/70-110/120 см) - сизуватий, із сизувато-сірими горизонтальними та вертикальними прожилками, щільність яких із глибиною поступово спадає; сітчаста текстура верхньої частини шару поступово “розріджується" і переходить у сітчасто-шарувату.

Грунт визначено як опідзолений мерзлотно-глейовий.

Прогумусований прошарок темно-сірого кольору в обох розрізах зазвичай плікативно деформований разом із низом сизувато-сірого шару середнього глейового горизонту і верхньою частиною власне ВГ; типові плавні деформовані 3 амплітудою до 0,25 м і довжиною “хвиль” до 1,0 м, але трапляються і вдвічі більші. Завдяки колірній контрастності цього прошарку місцями виразно проявляються морфологічно складніші зім'яття, схожі на кріотурбації (див. рис. 12). Їхнє утворення відбулось під час захоронення ВГ. Згідно з описом авторів праці (Богуцький та ін., 2016), на цьому ж стратиграфічному рівні у розрізі Солонське 2 широко розвинені крупні структури типу плям-медальйонів.

8. Нижній глейовий горизонт (18,6-25,1 м і більше) - суглинки переважно сильно оглеєні, сизі, сірувато- та зеленувато-сизі і сизуваті, зі смугами та плямами більш і менш інтенсивного озалізнення. Трапляються лінзи і прошарки, збагачені манганом. Суглинки здебільшого тугопластичні й важкі, близькі до глини.

У верхній і нижній частинах шару, а також безпосередньо біля його основи наявні підгоризонти піскуватих відкладів, явно та приховано шаруватих. Верхній підгоризонт таких відкладів виявлено в центральній частині палеопідняття, яке унаочнене порівняно високим положенням сірого ВГ. Він залягає на глибині до 2,0-2,5 м від верхньої межі горизонту. Потужність підгоризонту близько 0,4 м. Його представляють сірувато-сизі суглинки з лінзами та лінзоподібними прошарками світло-сірого тонкозернистого піску потужністю до $1 \mathrm{~cm}$.

Середній підгоризонт піскуватих відкладів невиразно шаруватий і озалізнений, має порівняно значну товщину (близько 0,6 м). Його покрівля розміщена на висоті близько 2,5 м над підошвою шару. В середній частині підгоризонту, безпосередньо над чорною смужкою оксиду мангану, наявний прошарок тонкозернистого мулистого піску. Зауважено, що нижче цього підгоризонту оглеєний суглинок крихкий, а над ним - звичайний, тугопластичний.

Нижній піскуватий підгоризонт (фактично, сильно озалізнений і зцементований тонкий прошарок потужністю до 10 см) приурочений до підошви шару контакту товщі суглинисто-глинистих відкладів і підстильного галечникового горизонту (рис. 14).

У нижній частині горизонту - в інтервалі до 0,5 м від його основи - трапляються поодинокі включення дрібної гальки та гравію. Їхня кількість помітно збільшується з наближенням до підошви шару. 
Р. Гнатюк, І. Папіш. Солонський розріз...

Видима потужність глейового горизонту в центральній частині розрізу Солонське 2 сягає 6,5 м. Дійсна потужність шару, визначена шляхом зіставлення цієї частини розрізу із крайнім західним відслоненням у кар'єрі, в якому розкрито його контакт із відкладами галечникового горизонту, близька до 7,5 м.

У разі такого визначення максимальної товщини горизонту потужність надгалечникового покриву тераси у зведеному розрізі відслонення Солонське 2 становитиме близько $26 \mathrm{м}$.

9. Галечниковий горизонт тераси розкритий у західній частині відслонення Солонське 2 поблизу дороги від кар'єру до цегельного заводу. Верхню половину його розрізу потужністю близько 2 м формує товща піщано-гравійно-галькових руслових відкладів з лінзою піску у середній частині. Нижче залягає валунний галечник, видима потужність якого перевищує 1,4 м. Крупні уламки галечнику представлені породами флішової формації Карпат.

Інтерпретація розрізу та обговорення головних результатів дослідження. Дискусійні питання, пов'язані з предметом дослідження, згрупуємо у три блоки.

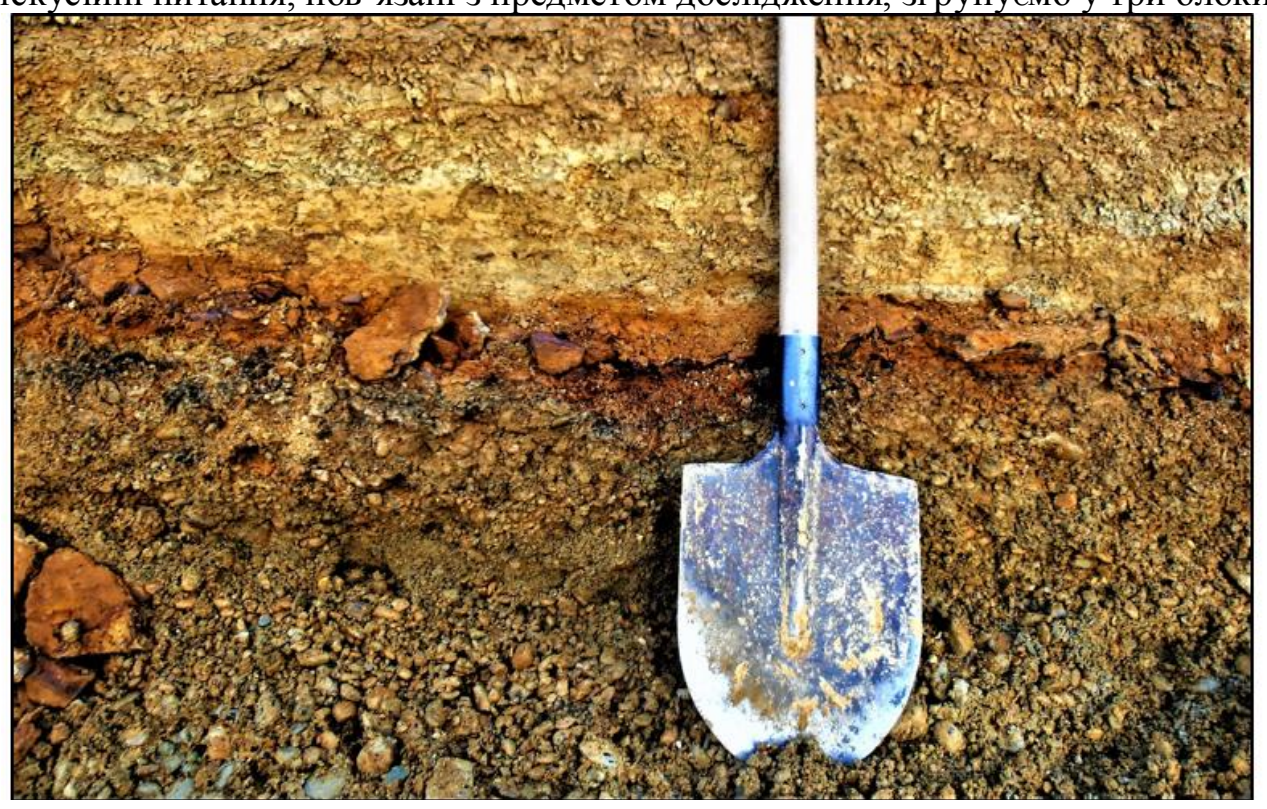

Рис. 14. Контакт заплавних (оглеєні та озалізнені суглинки, пилуваті піски) і руслових (гравійно-галечник) відкладів у розрізі Солонське 2

Fig. 14. Contact of the floodplain deposits (loam, gleyed and enriched of iron compounds, silty sands) and channel (gravel) deposits in the section Solonske 2

1. Генетична інтерпретація покривних (надгалечникових) відкладів та умови ӥхнього нагромадження. Беручи до уваги залягання плейстоценових шарів (гор. 2-5) так званої лесово-грунтової серії зведеного розрізу солонської тераси та їхнє співвідношення із рельєфом земної поверхні, а також літологічні особливості відкладів цієї серії (зокрема, безкарбонатність і щільність порід так званих лесових горизонтів, їхній важкий гранулометричний склад), не властиві для покривних відкладів Придністер'я еолового та еолово-делювіального генезису, можна передбачати, що зазначені вище шари складені річковим 
алювієм, нагромадженим в умовах заплави. Цей здогад підтверджують численні включення крупних уламків карпатських порід, виявлені у нижній частині (гор. 3) верхнього ярусу “лесу” та в верхньому ВГ розрізу Солонське 2, вододільне положення якого унеможливлює привнесення цих уламків в середовище нагромадження дрібно- й тонкозернистих осадів схиловими чи пролювіальними процесами, а також і відповідне походження відкладів, що вміщують крупноуламковий матеріал. Останній трапляється також і в нижніх суглинистоглинистих шарах (гор. 6 і 8), які, як і яруси суглинистих відкладів, що стали основою для формування грунтів так званої лесово-грунтової серії головного солонського розрізу, слід розглядати як алювіальні утворення.

Зазначимо, що включення крупних уламків карпатських порід у різних інтервалах розрізу верхньої (надгалечникової) товщі терасових відкладів притаманні вододільним розрізам різновікових плейстоценових терас різних підрайонів Придністер'я та Передкарпатської алювіальної рівнини (Гнатюк, 2017), але у межах великого солонського відслонення вони трапляються значно частіше, ніж у товщі імовірно річкових надгалечникових відкладів інших відомих відслонень (Дубрівка, Загвіздя, Галич), що містять значну кількість похованих грунтів і сприймаються як опорні розрізи плейстоцену Передкарпаття (Гляціал і перигляціал ..., 2011; Lessy i paleolit ..., 2002). Ця обставина підносить науково-пізнавальне значення великого солонського розрізу.

Є вагомі підстави вважати, що нагромадження відкладів усіх або майже усіх ярусів покривної товщі солонських розрізів (кожен ярус увінчує грунт, який долучаємо до його складу) відбувалось у порівняно суворих кліматичних умовах, які були достатньо холодними для розвитку процесів і форм, властивих перигляціальному літо- i морфогенезу. Зокрема, верхня частина найнижчого надгалечникового ярусу має ознаки, характерні для місцевих терасових ярусів перигляціального та субперигляціального типу (Гнатюк, 2012): хвилястість покрівлі ярусу, пов'язану з утворенням локальних еолових піднять на поверхні заплави; підвищену піскуватість його розрізу, зумовлену наявністю піщаних прошарків і лінз еолового та річкового походження; виразну шаруватість відкладів ярусу чи окремих інтервалів його розрізу, пов' язану із наявністю цих же утворень.

Відклади наступного ярусу покривної товщі разом із верхньою частиною підстильного ВГ (гор. 7) зім'яті у пологі складки інволютного типу; на цьому ж рівні трапляються значно контрастніші зім'яття, схожі на кріотурбації. Плавні плікативні деформації зафіксовано також у вище розміщених інтервалах солонських розрізів, зокрема поблизу контакту підгоризонтів 4.4 i 4.3.

Утім у розрізах відсутні безсумнівні кріогенні деформації розривного (структурного) типу, особливо важливі для реконструкцій геокріологічних і палеокліматичних умов. Зазначимо також, що нема підстав для розгляду плямисто-смугастих шарів, що приурочені, зазвичай, до нижніх інтервалів ярусів, розміщених безпосередньо над ВГ, зокрема так званої надкоршівської соліфлюкційної пачки, як соліфлюкційних утворень. Не погоджуємось і з тим, що верхні горизонти цих ВГ були перевідкладені чи знищені соліфлюкцією (Богуцький та ін., 2016). Утворення різнобарвних форм, схожих на плями-медальйони (див. рис. 4 у зазначеній вище праці), ми схильні пов'язувати із міграцією речовини, стимульованою глейовим процесом.

2. Умови утворення глейових горизонтів $i$ ВГ та ӥхнє 
Р. Гнатюк, І. Папіш. Солонський розріз...

хроностратиграфічне значення. Малопотужні глейові горизонти, визначені авторами статті (Богуцький та ін., 2016) у верхній частині грунтово-лесової серії (гор. 2 і 3 нашого зведеного розрізу) й інтерпретовані як поховані діяльні шари, не творять витриманих за простяганням прошарків й не мають стратиграфічного значення (винятком може бути верхній глейовий прошарок, фіксований на глибині 1,6-2,5 м, який, імовірно, відповідає фраджипену денного грунту). Важливішими для стратифікації солонських розрізів є потужні глейові шари (гор. 3 i 6 нашого опису), приурочені до нижніх частин міжгрунтових суглинистих товщ. Утім навряд чи можна вважати, що ці шари відображають якісь палеогеографічні етапи (наприклад, етапи гумідизації клімату) i $\epsilon$ повноцінними стратиграфічними виділами. Беручи до уваги принципову подібність обох шарів, виразну хвилястість позірної нижньої межі верхнього глейового горизонту, ії явно вторинний (накладений) характер, а також значну неоднорідність у рівні оглеєння суглинків цього шару - аж до наявності крупних включень майже не оглеєних лесоподібних порід (див. рис. 4), які місцями займають значну частину його розрізу, можна передбачати, що глейові горизонти, утворені внаслідок перезволоження відповідних інтервалів покривної товщі грунтовими водами і нині фіксують положення ії реліктових водоносних шарів. Отже, ці горизонти розрізу можуть мати суто епігенетичне (постседиментаційне) походження. Утім їхне утворення могло відбуватись лише у певні палеогеографічні етапи, сприятливі для формування чи значного підняття верхнього горизонту підземних вод. Такі етапи могли бути зумовлені піднесенням днищ річкових долин у разі виповнення раніше утворених ерозійних врізів $\mathrm{i} /$ чи зволоженням клімату під час формування відповідного ярусу покривної товщі тераси або й пізніше. Отож питання щодо хроностратиграфічного значення двох зазначених вище шарів залишається все ще відкритим.

Утворення нижнього глейового горизонту покривної товщі тераси розпочалось мабуть ще на завершальному етапі першого (найдавнішого) ерозійно-акумулятивного циклу в умовах формування заплави і продовжувалось пізніше, зокрема, під час утворення середнього глейового горизонту (обидва горизонти фактично творять одну потужну товщу сильно оглеєних суглинистих відкладів, у верхній половині якої наявний похований глейовий грунт).

Стратиграфічний ранг похованих грунтів вивчених солонських розрізів різний. Два верхні ВГ (підгор. 4.1, 4.2) зведеного розрізу, з огляду на значну потужність грунтового профілю, близьку до потужності сучасного грунту, та його морфологічні ознаки, слід розглядати як утворення міжльодовикового типу. Натомість два нижні ВГ (підгор. 4.4 і гор. 6) з їхнім значно коротшим профілем та ознаками посткріогенних текстур у різних інтервалах їхнього розрізу можна доволі впевнено зачислити до інтерстадіальних утворень. Характерно, що верхні частини цих грунтів зазнали виразно проявленого зім'яття на початкових етапах їхнього поховання. Щодо деформацій дефлюкційного генезису, які локально проявлені у верхній частині ВГ гор. 4 (див. рис. 7), то вони разом із ознаками іiі епігенетичного оглеєння можуть засвідчувати перезволоження грунту, спричинене погіршенням кліматичних умов безпосередньо перед його похованням.

Зазначені висновки щодо умов формування ВГ та їхньої стратиграфічної зна- 
чимості не узгоджені із результатами вивчення солонських розрізів, опублікованими раніше. Особливо значні розбіжності між нашою інтерпретацією та інтерпретацією М. Веклича (Веклич, 1982), який два верхні ВГ буроземного типу зіставив із витачівським палеогеографічним етапом (фактично, інтерстадіалом), а нижній, мерзотно-глейовий (?) ВГ вивчених нами розрізів, відніс до прилуцької міжльодовикової епохи.

3. Стратиграфія покривної (надгалечникової) частини розрізу. Вік mераси. Стратиграфічне розчленування покривної товщі солонських розрізів, здійснене попередніми дослідниками (Богуцький та ін., 2016; Веклич, 1982), попри однакову вихідну позицію у питанні походження відкладів так званої грунтово-лесової серії, виявилось суттєво різним. Фактично, жодний із легко впізнаваних спільних (одновікових) “грунтових" і “міжгрунтових" шарів, виокремлених у вивчених ними відслоненнях (Солонське 1 і Солонське 2), не отримав однакової чи навіть близької хроностратиграфічної інтерпретації.

За результатами наших досліджень, у покривній товщі солонської тераси під денним грунтом доцільно виокремити принаймні вісім шарів, що мають хроностратиграфічне значення. Верхній із них об'єднує 2-й і 3-й шари наведеного вище опису, 2-й і 3-й відповідають двом добре розвиненим ВГ міжльодовикового типу, 4-й - малопотужному “міжтрунтовому” підгор. 4.3, 5-й - верхньому ВГ міжстадіального типу (підгор. 4.4); 6-й хроностратиграфічний шар об’єднує два наступні шари зведеного розрізу - нижній горизонт оглеєних лесоподібних суглинків і середній глейовий горизонт; 7-й і 8-й шари відповідають однойменним шарам вивчених солонських відслонень. Як бачимо із переліку шарів, їхній стратиграфічний ранг різний.

Загалом, беручи до уваги висновки щодо палеокліматичних умов, у яких відбувалось нагромадження відкладів покривної товщі i формування та перетворення вміщених у ній ВГ, у доголоценовій частині іiі розрізу можна виокремити три стратиграфічні горизонти високого (льодовикового/міжльодовикового) рангу.

Нижній із цих шарів, утворений у льодовикову епоху, охоплює всю чи майже всю нижню частину покривної товщі до “міжгрунтового” підгор. 4.3 включно. Наступний - середній шар - відображає міжльодовикову епоху: йому відповідає світа добре розвинених ВГ буроземного типу (грунти коршівського викопного грунтового комплексу, згідно з описом авторів праці (Богуцький та ін., 2016)), утворених головно під час іiї термалів. Верхній горизонт високого стратиграфічного рангу об'єднує 2-й і 3-й шари описаного вище розрізу і представляє наступну льодовикову епоху (холодну стадію морської ізотопної шкали).

Вивчення солонської тераси - висотного положення ії поверхні та будови покривної частини, імовірно ії ж розрізів у басейні верхнього Дністра, - дає підстави вважати, що вона одновікова 3 терасою Стривігору-Дністра, будова якої розкрита в кар'єрі поблизу с. Дубрівка (Гляціал і перигляціал ..., 2011). Важливо, що в цьому розрізі, принципово подібному до солонських відслонень, у стратиграфічній позиції, що відповідає “міжтрунтовому” підгор. 4.3 - наймолодшому підрозділу нижнього “льодовикового” горизонту покривної товщі солонської тераси, наявні окремо розміщені крупні уламки ератичних порід (у тому числі валуни довжиною понад 0,5 м), принесені, найімовірніше, 3 крижинами та брилами льоду, а, можливо, і справжні льодовикові та озерно-льодовикові 
відклади, описані в публікаціях (Гляціал і перигляціал ..., 2011; Łanczont et al., 2019). Ці включення засвідчують близьку чи безпосередню присутність скандинавського льодовика, окський вік якого в басейні Дністра вважають нині доведеним (Герасімов та ін., 2005; Krokhmal \& Komar, 2018; Lanczont et al., 2019), на заключному етапі утворення нижнього алювіального (гляціоалювіального) комплексу дубрівської тераси, а також і відповідний (окський, тилігульський, сан-2) вік нижнього “льодовикового” горизонту покривної товщі солонської тераси. Вік “міжльодовикового” середнього горизонту цієї ж товщі у разі такого визначення часу утворення її нижнього стратиграфічного горизонту (підгор. 4.3 і нижче) відповідно до кореляції палеогеографічних етапів четвертинного періоду України, Східної і Західної Європи (Просторово-часова кореляція ..., 2009), буде ранньозавадівським-лихвинським-гольштейнським (11та МIC), а верхнього - середньозавадівським (10-та МIC) .

Отже, згідно із результатами наших досліджень, утворення солонської тераси відбувалось під час трьох стадій морської ізотопної шкали - 12-ї, 11-ї і 10-ї. Якщо ж червоно-бурий лісовий грунт, визначений М. Векличем у розрізі Солонське 1, насправді існує і виявиться утворенням міжльодовикового типу, початок формування тераси слід зачислити до 13-ї МIC.

Відповідна тераса Галицького Придністер'я названа довгівською й віднесена до комплексу середніх терас (Гнатюк, 2012). У Молдовському Придністер'ї цю ж терасу віддавна називають варницькою (варніцкою) (Гнатюк, 2014; Чепалыга, 1986). Домінує уявлення (Гнатюк, 2014, табл. 2), яке, мабуть, не зовсім відповідає реальності (але до неї близьке), що тераса формувалась упродовж першої половини середнього неоплейстоцену.

Висновки та перспективи подальших досліджень. Розрізи плейстоценових відкладів у районі с. Солонське - типові відслонення добре збереженої покривної (надгалечникової) товщі порівняно високих терас пригірської частини Передкарпатської височини, складеної алювіальними суглинками та глинами. Тут, як і в інших типових розрізах місцевих терас, наявні лише алювіальні яруси лесоподібних та інших пилуватих порід, увінчані добре чи слабко розвиненими викопними грунтами. Важливо, що солонські розрізи представляють переконливі свідчення річкового походження відкладів цих ярусів і розкривають будову тераси, що має значне поширення у басейні верхнього Дністра і $є$ порівняно легко впізнаваною 3 огляду на характерну будову товщі покривних (заплавних) відкладів.

Важливо також, що ці розрізи містять порівняно значну кількість похованих грунтів, у тому числі й доволі специфічний мерзлотно-глейовий грунт інтерстадіального типу. Завдяки цьому вони є стратиграфічно повнішими, ніж інші відомі відслонення цієї ж тераси, розміщені у Самбірському (Дубрівка, Торгановичі 1 , 2) та Галицькому Придністер'ї (Довге). Зіставлення цих та інших розрізів із виділенням одновікових і різновікових алювіальних комплексів i, як наслідок, докладне обгрунтування віку солонської (дубрівської) тераси - завдання майбутніх досліджень і предмет окремої публікації чи публікацій.

Наразі зазначимо лише, що:

1) вивчення будови солонських розрізів не підтвердило нещодавно оприлюдненого уявлення про значно давніший, аніж це вважали раніше, ранньоплейстоценовий (донеоплейстоценовий) вік солонської тераси та необхідність 
віднесення іï до групи високих плейстоценових терас Українського Передкарпаття (рівня Лоєвої);

2) зведений солонський розріз не може бути опорним для стратиграфії нижнього-верхнього плейстоцену Передкарпаття, оскільки представляє невеликий стратиграфічний діапазон середньої частини середнього плейстоцену, у складі якого можна виокремити три або чотири стратиграфічні горизонти високого рангу, еквівалентні ярусам морської ізотопної шкали - 13-му (?), 12-му, 11-му і 10-му. Натомість він, як і інші багатоярусні розрізи “покривних товщ” порівняно давніх неоплейстоценових терас Українського Передкарпаття (Крукеничі, Дубрівка, Загвіздя, Галич та ін.), може бути опорним для вивчення кількох (двохтрьох) суміжних стратиграфічних горизонтів льодовикового та міжльодовикового рангу. Фактично, це один із найважливіших опорних розрізів солонської (дубрівської) тераси Верхнього Придністер'я.

\section{СПИСОК ВИКОРИСТАНОЇ ЛІТЕРАТУРИ}

Адаменко $A$. Четвертичная палеогеография экосистемы Нижнего и Среднего Днестра / Адаменко А. В., Гольберт В. А., Осиюк Ж. Н. и др. - Киев : Феникс, 1996. $-200 \mathrm{c}$.

Богуиьький А. Розріз Солонське і перспективи пізнання поверхні Лоєвої / А. Богуцький, А. Яцишин, Р. Дмитрук, О. Томенюк // Вісн. Львів. ун-ту. Серія геогр. - 2016. - Вип. 50. - С. 54-66.

Веклич М. Палеоэтапность и стратотипы почвенных формаций верхнего кайнозоя / М. Ф. Веклич - Киев : Наук. думка, 1982. - 202 с.

Герасімов Л. Державна геологічна карта України масштабу 1:200 000, аркуші М34-XXIII (Пшемисль), M-34-XXIV (Дрогобич). Карпатська серія. Пояснювальна записка / Герасімов Л. С., Макарова І. В., Чалий С. В. та ін. Київ : Держ. комітет природних ресурсів України, НАК Надра України, ДП Західукргеологія, Львівська геологорозвідувальна експедиція, 2005. - 133 с.

Гляціал і перигляціал Українського Передкарпаття: зб. наук. праць (до XVII укр.пол. семінару. Самбір, 15-18 вересня 2011 р.) / за ред. А. Богуцького. - Львів: ВЦ ЛНУ імені Івана Франка, 2011. - 306 с.

Гнатюк $P$. Десять позицій за річкове походження верхніх (супіщано-суглинистих) горизонтів плейстоценових терас Українського Передкарпаття та Середнього Придністер'я (частина 1) / Р. Гнатюк // Проблеми геоморфології і палеогеографії Українських Карпат і прилеглих територій: матеріали третього міжнар. семінару. - Львів : ВЦ ЛНУ ім. Івана Франка, 2008. - С. 111-127.

Гнатюк $P$. Десять позицій за річкове походження верхніх (супіщано-суглинистих) горизонтів плейстоценових терас Українського Передкарпаття та Середнього Придністер'я (частина 3) / Р. Гнатюк // Проблеми геоморфології і палеогеографії Українських Карпат і прилеглих територій: зб. наук. праць. Львів : ВЦ ЛНУ імені Івана Франка, 2012. - С. 203-218.

Гнатюк $Р$. Ще раз про покривні грунтово-лесові товщі на терасах Передкарпаття та Подільського Придністер'я та алювіальне походження лесів / Р. Гнатюк // Фізична географія та геоморфологія. - 2012. - Вип. 4 (68). - С. 187-193. 
Р. Гнатюк, І. Папіш. Солонський розріз...

Гнатюк Р. Стан вивчення плейстоценових терас Середнього Придністер'я / Р. Гнатюк // Історія української географії. Всеукраїнський науковотеоретичний часопис. - 2014. - Вип. 29, 30. - С. 97-107.

Гнатюк $Р$. Десять позицій за річкове походження верхніх (супіщано-суглинистих) горизонтів плейстоценових терас Українського Передкарпаття та Середнього Придністер'я (частина 4) / Р. Гнатюк // Проблеми геоморфології і палеогеографії Українських Карпат і прилеглих територій: зб. наук. праць. Львів : ВЦ ЛНУ ім. Івана Франка, 2017. - Вип. 01(07). - С. 85-101.

Демедюк Н. С. Антропогеновые отложения Украинских Карпат / Н. С. Демедюк // Антропогеновые отложения Украины. - Киев : Наукова думка, 1986. C. $133-145$.

Кравчук Я. С. Геоморфологія Передкарпаття / Я. С. Кравчук - Львів: Меркатор, 1999. $-188 \mathrm{c}$.

Паньків 3. Дерново-підзолисті поверхнево-оглеєні грунти північно-західного Передкарпаття / 3. П. Паньків, П.С. Позняк - Львів : Меркатор, 1998. - 132 с.

Польчина С. Гетерогенетичність профільно-диференційованих оглеєних грунтів Передкарпаття / С. М. Польчина // Наук. вісник Чернів. ун-ту. Біологія (Біол. системи). - 2012. - Т. 4. Вип. 2. - С. 197-201.

Польчина С. Процесна оцінка профільно-диференційованих оглеєних грунтів Передкарпатця / С. М. Польчина // Вісн. Львів. ун-ту. Серія геогр. - 2013. Вип. 44. - С. 295-301.

Просторово-часова корелячія палеогеографічних умов четвертинного періоду на території Украӥни: Монографія / Ж. М. Матвїшина, Н. П. Герасименко, В. І. Передерій та ін. - Київ: Наук. думка, 2009. - 193 с.

Чепалыга A. Террасы Днестра / А. Л. Чепалыга // Антропоген и палеолит Молдавского Приднестровья. Путеводитель экскурсий VI Всесоюзного совещания по изучению четвертичного периода. - Кишинев : Штиинца, 1986. - C. 57-62.

Gozhik $P$. Tarasy środkowego i dolnego Dniestru oraz ich znaczenie w badaniach nad plejstocenem Europy / P. Gozhik, L. Lindner // Systemy dolinne i ich funkcjonowanie. Prace Instytutu Geografii Akademii Świętokrzyskiej w Kielcach. T. 16. - 2007. - S. 27-42.

Krokhmal A. Reconstruction of palaeolandscapes of Ukraine during MIS 20-12 obtained by palaeontological methods / A. Krokhmal, M. Komar // Annales Maria Curie-Skłodowska University, sect. B. - Vol. LXXIII. - 2018. - P. 83-105. doi:10.17951/b.2018.73.83-105.

Łanczont M. Stratigraphy and chronology of the periphery of the Scandinavian ice sheet at the foot of the Ukrainian Carpathians / Lanczont M., Bogucki A., Yatsyshyn A. et al. // Palaeogeography, Palaeoclimatology, Palaeoecology. https://doi.org/10.1016/j.palaeo.2019. 05.024 (у друці).

Lessy i paleolit Naddniestrza halickiego (Ukraina) / Pod red. T. Madeyskiej // Studia geologica Polonica. Krakow, 2002. - Vol. 119. Częsc III. - 391 s.

\section{REFERENCES}

Adamenko, A. V., Golbert, V. A., Osiiuk, Zh. N., Matviishyna, Zh. N., Medianyk, S. I., Motok, V. E. ... Cherniuk A. V. (1996). Chetvertichnaja paleogeografija jekosistemy Nizhnego $i$ Srednego Dnestra [Quaternary 
Р. Гнатюк, І. Папіш. Солонський розріз...

paleogeography of ecosystems of Lower and Middle Dnister]. Kyiv: Feniks (in Ukrainian).

Bohutskyi, A., Yatsyshyn, A., Dmytruk, R., Tomeniuk, O. (2016). Rozriz Solonske i perspektyvy piznannia poverkhni Loievoi [Solonske section and the perspectives of the cognition of Loyeva level]. In Visn. Lviv. un-tu. Seriia geohr., 50, 54-66 (in Ukrainian).

Veklich, M.F. (1982). Paleojetapnost' $i$ stratotipy pochvennyh formacij verhnego kajnozoja [Paleo-stage and stratotypes of soil formations of the Upper Cenozoic]. Kyiv: Nauk. dumka (in Russian).

Herasimov, L. S., Makarova, I. V., Chalyi S. V., Plotnikov, A. A., Herasimova I. I., Polkunova, G. V., Evtushko, T. L. (2005). Derzhavna heolohichna karta Ukrainy masshtabu 1:200 000, arkushi M-34-XXIII (Pshemysl), M-34-XXIV (Drohobych). Karpatska seriia. Poiasniuvalna zapyska [State Geological Map of Ukraine in the scale 1:200 000, map sheets M-34-XXIII (Pshemysl) and M-34-XXIV (Drogobych). Carpathian Series. Explanatory Notes]. Kyiv: Derzhavnyi komitet pryrodnykh resursiv Ukrainy, NAK Nadra Ukrainy, DP Zakhidukrheolohiia, Lvivska heolohorozviduvalna ekspedytsiia (in Ukrainian).

Bohutskyi, A. (Eds.). (2011). Hliatsial i peryhliatsial Ukrainskoho Peredkarpattia [Glacjał i peryglacjał Wschodniego Podkarpacia]. In Zbirnyk nauk. prats do XVII ukr.pol. seminaru. Sambir, 2011 r. Lviv: VC LNU im. Ivana Franka (in Ukrainian).

Hnatiuk, R. (2008). Desiat pozytsii za richkove pokhodzhennia verkhnikh (supishchano-suhlynystykh) horyzontiv pleistotsenovykh teras Ukrainskoho Peredkarpattia ta Serednoho Prydnisteria (chastyna 1) [Ten arguments in favor of the river origin of the upper (sandy-loam and loamy) horizons of the Pleistocene terraces of Ukrainian Pre-Carpathian and Middle Transnistria (part 1)]. In Problemy heomorfolohii i paleoheohrafii Ukrainskykh Karpat i prylehlykh terytorii: zb. nauk. prats. Lviv: VC LNU im. Ivana Franka, 111-127. (in Ukrainian).

Hnatiuk, R. (2012). Desiat pozytsii za richkove pokhodzhennia verkhnikh (supishchano-suhlynystykh) horyzontiv pleistotsenovykh teras Ukrainskoho Peredkarpattia ta Serednoho Prydnisteria (chastyna 3) [Ten arguments in favor of the river origin of the upper (sandy-loam and loamy) horizons of the Pleistocene terraces of Ukrainian Pre-Carpathian and Middle Transnistria (part 3)]. In Problemy heomorfolohii i paleoheohrafii Ukrainskykh Karpat i prylehlykh terytorii: zb. nauk. prats. Lviv: VC LNU im. Ivana Franka, 203-218 (in Ukrainian).

Hnatiuk, R. (2012). Shche raz pro pokryvni gruntovo-lesovi tovshchi na terasakh Peredkarpattia ta Podilskoho Prydnisteria ta aliuvialne pokhodzhennia lesiv. In Fizychna heohrafiia ta heomorfolohiia, 4 (68), 187-193 (in Ukrainian).

Hnatiuk, R. (2014). Stan vyvchennia pleistotsenovykh teras Serednoho Prydnisteria [Pleistocene terraces of the Middle trans-Dniester area: a research state]. In Istoriia ukrainskoi heohrafii. Vseukrainskyi naukovo-teoretychnyi chasopys, 29,30, 97-107 (in Ukrainian).

Hnatiuk, R. (2017). Desiat pozytsii za richkove pokhodzhennia verkhnikh (supishchano-suhlynystykh) horyzontiv pleistotsenovykh teras Ukrainskoho Peredkarpattia ta Serednoho Prydnisteria (chastyna 4) [Ten arguments in favor of the river origin of the upper (sandy-loam and loamy) horizons of the Pleistocene terraces of Ukrainian Pre-Carpathian and Middle Transnistria (part 4)]. In Problemy 
Р. Гнатюк, І. Папіш. Солонський розріз...

100

ISSN 2519-2620. Проблеми геоморфології і палеогеографії...2019. Вип. 1 (9), 73-100

heomorfolohii i paleoheohrafii Ukrainskykh Karpat i prylehlykh terytorii: zb. nauk. prats, 01(07). Lviv: VC LNU imeni Ivana Franka, 85-101 (in Ukrainian).

Demedjuk, N. S. (1986). Antropogenovye otlozhenija Ukrainskih Karpat [Anthropogenic deposits of the Ukrainian Carpathians]. In Antropogenovye otlozhenija Ukrainy, Kyiv: Naukova dumka, 133-145 (in Russian).

Kravchuk, Ya. S. (1999). Heomorfolohiia Peredkarpattia [Geomorphology of Precarpathian]. Lviv: Merkator. ISBN 966-7563-00-6 (in Ukrainian).

Pankiv, Z. P., Pozniak, S. P. (1998). Dernovo-pidzolysti poverkhnevo-ohleieni grunty pivnichno-zakhidnoho Peredkarpattia [Sod-podzolic surface-gleied soils of northwestern Precarpathian region]. Lviv: Merkator. ISBN 966-7379-06-X (in Ukrainian).

Pol'chyna, S. M. (2012). Heterohenetychnist profilno-dyferentsiiovanykh ohleienykh gruntiv Peredkarpattia [The heterogenetic of Precarpathians profile-differented gleied soils]. In Nauk. visnyk Cherniv. un-tu. Biolohiia (Biol. systemy), 4/2, 197201 (in Ukrainian).

Pol'chyna, S. (2013). Protsesna otsinka profilno-dyferentsiiovanykh ohleienykh gruntiv Peredkarpattia [Process evaluation of profile-differentiated gleied soils of Precarpathians]. In Visn. Lviv. un-tu. Seriia geohr. 44, 295-301 (in Ukrainian).

Matviishyna, Zh. M, Gerasimenko, N. P., Perederiy, V. I., Bragin, A. M., Ivtchenko, A. S., Karmazynenko, S. P. ... Parkhomenko, O. G. (2009). Prostorovo-chasova koreliatsiia paleoheohrafichnykh umov chetvertynnoho periodu na terytorii Ukrainy [Spatial-temporal correlation of Quaternary paleogeography conditions in Ukraine territory]. Kyiv: Naukova dumka (In Ukrainian).

Chepalyga, A. L. (1986). Terrasy Dnestra [Terraces of the Dniester]. In Antropogen $i$ paleolit Moldavskogo Pridnestrov'ja. Putevoditel' jekskursij VI Vsesojuznogo soveshhanija po izucheniju chetvertichnogo perioda. Kishinev: Shtiinca, 57-62 (in Russian).

Gozhik, P., Lindner, L. (2007). Tarasy środkowego i dolnego Dniestru oraz ich znaczenie $\mathrm{w}$ badaniach nad plejstocenem Europy. In Systemy dolinne $i$ ich funkcjonowanie. Prace Instytutu Geografii Akademii Świętokrzyskiej w Kielcach, 16, 27-42 (in Polish).

Krokhmal, A., Komar, M., 2018. Reconstruction of palaeolandscapes of Ukraine during MIS 20-12 obtained by palaeontological methods. In Annales Maria CurieSkłodowska University, sect. B, 73, 83-105.

Łanczont, M., Bogucki, A., Yatsyshyn, A., Terpiłowski, S., Przemysław, M., Orłowska, A., Hołub, B., Zieliński, P., Komar, M., Woronko, B., Kulesza, P., Dmytruk, R., Tomeniuk, O. Stratigraphy and chronology of the periphery of the Scandinavian ice sheet at the foot of the Ukrainian Carpathians. In Palaeogeography, Palaeoclimatology, Palaeoecology. doi.org/10.1016/j.palaeo.2019.05.024

Madeyska, T. (Eds.). (2002). Lessy i paleolit Naddniestrza halickiego (Ukraina). Studia geologica Polonica, 119, III. Krakow (In Polish). 